\title{
A review of global environmental mercury processes in response to human and natural perturbations: Changes of emissions, climate, and land use
}

\author{
Daniel Obrist, Jane L. Kirk, Lei Zhang, Elsie M. Sunderland $(\mathbb{D}$, \\ Martin Jiskra, Noelle E. Selin (1)
}

Published online: 31 January 2018

\begin{abstract}
We review recent progress in our understanding of the global cycling of mercury $(\mathrm{Hg})$, including best estimates of $\mathrm{Hg}$ concentrations and pool sizes in major environmental compartments and exchange processes within and between these reservoirs. Recent advances include the availability of new global datasets covering areas of the world where environmental $\mathrm{Hg}$ data were previously lacking; integration of these data into global and regional models is continually improving estimates of global $\mathrm{Hg}$ cycling. New analytical techniques, such as $\mathrm{Hg}$ stable isotope characterization, provide novel constraints of sources and transformation processes. The major global $\mathrm{Hg}$ reservoirs that are, and continue to be, affected by anthropogenic activities include the atmosphere (4.4-5.3 $\mathrm{Gt}$ ), terrestrial environments (particularly soils: $250-1000$ $\mathrm{Gg}$ ), and aquatic ecosystems (e.g., oceans: 270-450 Gg). Declines in anthropogenic $\mathrm{Hg}$ emissions between 1990 and 2010 have led to declines in atmospheric $\mathrm{Hg}^{0}$ concentrations and $\mathrm{Hg}^{\mathrm{II}}$ wet deposition in Europe and the US ( -1.5 to $-2.2 \%$ per year). Smaller atmospheric $\mathrm{Hg}^{0}$ declines $(-0.2 \%$ per year) have been reported in high northern latitudes, but not in the southern hemisphere, while increasing atmospheric $\mathrm{Hg}$ loads are still reported in East Asia. New observations and updated models now suggest high concentrations of oxidized $\mathrm{Hg}^{\mathrm{II}}$ in the tropical and subtropical free troposphere where deep convection can scavenge these $\mathrm{Hg}^{\mathrm{II}}$ reservoirs. As a result, up to $50 \%$ of total global wet $\mathrm{Hg}^{\mathrm{II}}$ deposition has been predicted to occur to tropical oceans. Ocean $\mathrm{Hg}^{0}$ evasion is a large source of present-day atmospheric $\mathrm{Hg}$ (approximately $2900 \mathrm{Mg} /$ year; range 1900-4200 Mg/year). Enhanced seawater $\mathrm{Hg}^{0}$ levels suggest enhanced $\mathrm{Hg}^{0}$ ocean evasion in the intertropical convergence zone, which may be linked to high $\mathrm{Hg}^{\mathrm{II}}$ deposition. Estimates of gaseous $\mathrm{Hg}^{0}$ emissions to the atmosphere over land, long considered a
\end{abstract}

critical $\mathrm{Hg}$ source, have been revised downward, and most terrestrial environments now are considered net sinks of atmospheric $\mathrm{Hg}$ due to substantial $\mathrm{Hg}$ uptake by plants. Litterfall deposition by plants is now estimated at $1020-1230 \mathrm{Mg} / \mathrm{year}$ globally. Stable isotope analysis and direct flux measurements provide evidence that in many ecosystems $\mathrm{Hg}^{0}$ deposition via plant inputs dominates, accounting for $57-94 \%$ of $\mathrm{Hg}$ in soils. Of global aquatic $\mathrm{Hg}$ releases, around 50\% are estimated to occur in China and India, where $\mathrm{Hg}$ drains into the West Pacific and North Indian Oceans. A first inventory of global freshwater $\mathrm{Hg}$ suggests that inland freshwater $\mathrm{Hg}$ releases may be dominated by artisanal and small-scale gold mining (ASGM; approximately $880 \mathrm{Mg} / \mathrm{year}$ ), industrial and wastewater releases $(220 \mathrm{Mg} / \mathrm{year})$, and terrestrial mobilization (170-300 Mg/year). For pelagic ocean regions, the dominant source of $\mathrm{Hg}$ is atmospheric deposition; an exception is the Arctic Ocean, where riverine and coastal erosion is likely the dominant source. Ocean water $\mathrm{Hg}$ concentrations in the North Atlantic appear to have declined during the last several decades but have increased since the mid-1980s in the Pacific due to enhanced atmospheric deposition from the Asian continent. Finally, we provide examples of ongoing and anticipated changes in $\mathrm{Hg}$ cycling due to emission, climate, and land use changes. It is anticipated that future emissions changes will be strongly dependent on ASGM, as well as energy use scenarios and technology requirements implemented under the Minamata Convention. We predict that land use and climate change impacts on $\mathrm{Hg}$ cycling will be large and inherently linked to changes in ecosystem function and global atmospheric and ocean circulations. Our ability to predict multiple and simultaneous changes in future $\mathrm{Hg}$ global cycling and human exposure is rapidly developing but requires further enhancement. 
Keywords Climate change Emission change Heavy metal · Land use change .

Mercury global environmental cycling

\section{INTRODUCTION}

Our understanding of the critical processes driving global mercury $(\mathrm{Hg})$ cycling, in particular those that affect largescale exchange of $\mathrm{Hg}$ among major environmental compartments, has advanced substantially over the past decade. Progress has been driven by major advances in three interconnected areas: new data, new models, and new analytical tools and techniques. In this paper, we summarize the state of knowledge of the major global $\mathrm{Hg}$ reservoirs in the Earth system: the atmosphere, terrestrial ecosystems, and aquatic ecosystems. We describe the constraints on processes that control $\mathrm{Hg}$ exchanges between these reservoirs, and the relative influences of policy, land use, climate change, and anthropogenic disturbances on $\mathrm{Hg}$ cycling (Fig. 1).

Analyses of newly available data in the context of advances in modeling capabilities and novel analysis techniques have improved our understanding of fundamental processes relevant to $\mathrm{Hg}$ cycling. In the past decade, new data have become available from areas of the world where they previously were lacking, including Asia, the tropics, and the southern hemisphere. Environmental models are increasingly used for synthesizing global observations and describing the mechanisms driving $\mathrm{Hg}$ speciation, cycling, and bioavailability. Global three-dimensional (3D) models of $\mathrm{Hg}$ in the atmosphere (Dastoor and Larocque 2004; Selin et al. 2007; Jung et al. 2009; Travnikov and Ilyin 2009; Holmes et al. 2010; Durnford et al. 2012; Bieser et al. 2017; Horowitz et al. 2017), terrestrial ecosystems (Smith-Downey et al. 2010), and oceans (Zhang et al. 2014, 2015b; Semeniuk and Dastoor 2017) have improved our understanding of $\mathrm{Hg}$ processes. A major advance has been the development of a hierarchy of modeling tools that collapse the necessary detail from global simulations into more computationally feasible geochemical box models, enabling fully coupled simulations of the interactions among the land, atmosphere, and oceans over millennial time scales (Amos et al. 2013, 2014, 2015). When combined with information on the cumulative history of human $\mathrm{Hg}$ release from antiquity to the present, this modeling approach has revealed a much greater contribution of human activity to the global $\mathrm{Hg}$ cycle than previously recognized (Streets et al. 2011, 2017). The last 10 years has also seen rapid

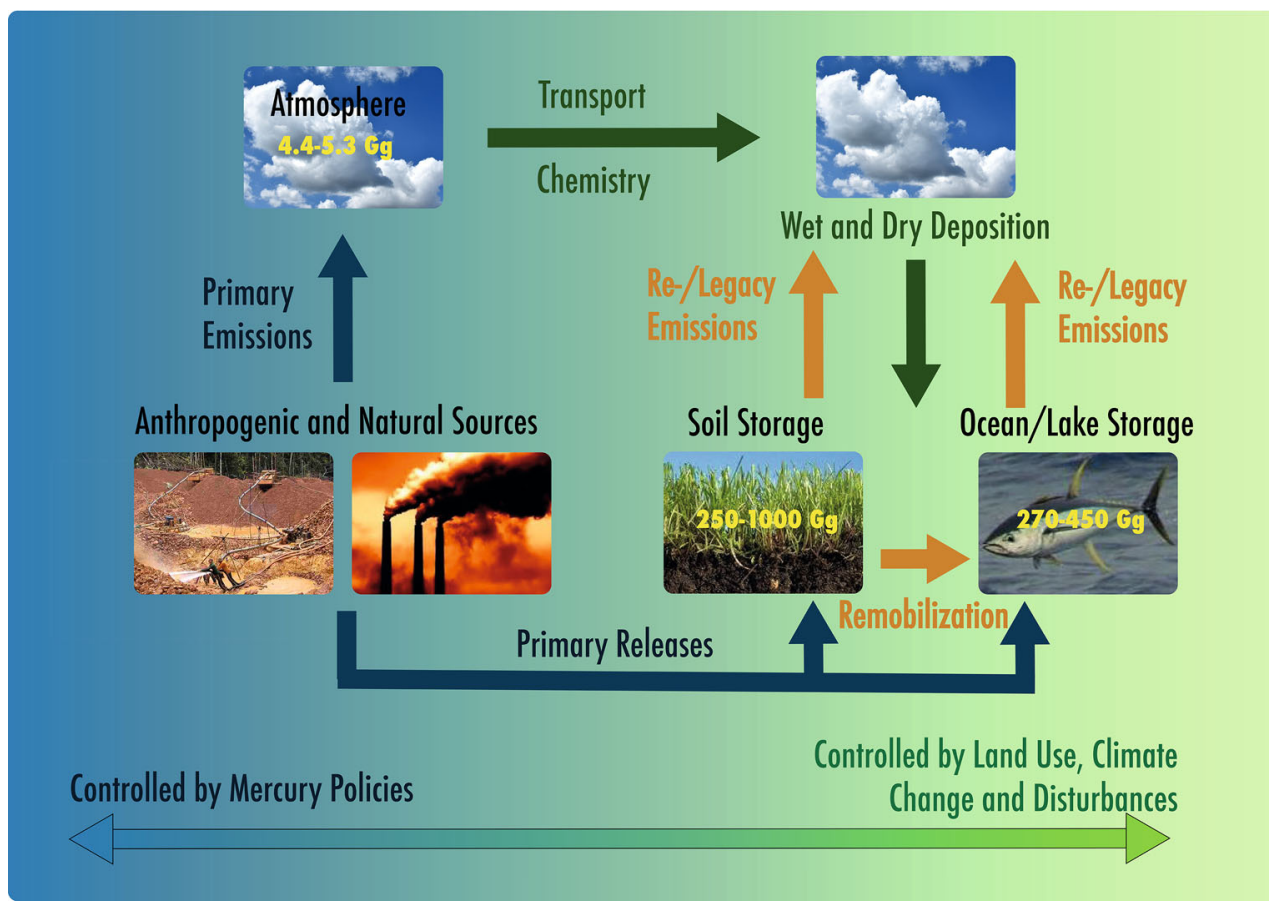

Fig. 1 Overview of global $\mathrm{Hg}$ cycling and impacts of policies and global change. Yellow numbers are estimated pool sizes in global reservoirs, and arrows indicate exchange processes between major environmental reservoirs. Pool sizes and exchanges are strongly modulated by anthropogenic emissions and releases (blue arrows) which transform in the atmosphere and deposit to aquatic and terrestrial ecosystems (green arrows). The $\mathrm{Hg}$ cycle will continue to experience disturbances due to changes in anthropogenic emissions and will be increasingly affected by land use and climate change, which remobilize (orange arrows) $\mathrm{Hg}$ that has accumulated in environmental reservoirs from previous $\mathrm{Hg}$ emissions and releases 
development in $\mathrm{Hg}$ stable isotope biogeochemistry, providing a valuable tool to quantify $\mathrm{Hg}$ sources and study transformation processes. Incorporation of $\mathrm{Hg}$ stable isotopes in global models has the potential to constrain the relative importance of specific sources and processes (Sonke 2011; Sun et al. 2016a) (See Box 1).

These recent advances have proven particularly valuable for investigating the anticipated impacts of human and natural perturbations on global $\mathrm{Hg}$ cycling. Changes in anthropogenic emissions are ongoing and will continue into the future, including strong shifts in global source areas compared to current emission patterns (Giang et al. 2015). Accelerating land use and climate change are expected to have significant effects on global, regional, and local $\mathrm{Hg}$ cycles, with unexpected feedbacks and nonlinear impacts on $\mathrm{Hg}$ exposure. Models have been applied to assess the impact of regulatory interventions, such as emission controls (Selin et al. 2018), on specific outcomes and to evaluate policy efforts to mitigate $\mathrm{Hg}$ pollution (Selin 2014). An increasing number of studies are now available documenting such changes.

Here, we review the major insights gained from scientific advances over the past decade on global $\mathrm{Hg}$ cycling and $\mathrm{Hg}$ exchanges within and among the environmental compartments of the atmosphere, terrestrial ecosystems, and aquatic ecosystems. We then synthesize this knowledge to assess the impacts of human activities, including those affected by $\mathrm{Hg}$-specific and other environmental policies, on the future of global $\mathrm{Hg}$ cycling. Further detailed discussion of factors affecting aquatic Hg loading, $\mathrm{Hg}$ methylation and demethylation processes, and exposure of wildlife and humans to $\mathrm{Hg}$ in the context of environmental change and disturbances are provided by EaglesSmith et al. (2018) and Hsu-Kim et al. (2018), while relevant scientific insights for global policy are described in Selin et al. (2018).

\section{RECENT ADVANCES IN UNDERSTANDING CRITICAL HG CYCLING PROCESSES OF GLOBAL IMPORTANCE}

In this section, we discuss critical processes of importance for $\mathrm{Hg}$ cycling within (Fig. 2, blue arrows) and between (Fig. 2, red arrows) major environmental compartments (atmosphere, terrestrial, and aquatic [freshwater and ocean]).

\section{Atmosphere}

Atmospheric total gaseous mercury (TGM) concentrations have been measured since the late 1970s, with more reliable observations emerging since approximately 1990
(Slemr et al. 2003; Lindberg et al. 2007; Temme et al. 2007; Sprovieri et al. 2010; Slemr et al. 2011; Sprovieri et al. 2016). Mean TGM concentrations in background areas in the northern hemisphere, the tropics, and the southern hemisphere are $1.3-1.6,1.1-1.3$, and $0.8-1.1 \mathrm{ng} /$ $\mathrm{m}^{3}$, respectively (Slemr et al. 2011; Sprovieri et al. 2016). Many observations show that in the past three decades global background TGM concentrations have declined, particularly in North America, Europe, and over the North Atlantic Ocean (Slemr et al. 2003; Lindberg et al. 2007; Temme et al. 2007; Slemr et al. 2008; Ebinghaus et al. 2011; Slemr et al. 2011; Soerensen et al. 2012; Cole et al. 2013; Weigelt et al. 2015; Sprovieri et al. 2016), with rates of declines between -1.5 and $-2.2 \%$ per year. Because anthropogenic emission inventories did not support such declines, proposed drivers for declines include decreased $\mathrm{Hg}$ concentrations and subsequent evasion in the upper North Atlantic Ocean and/or changes in terrestrial surfaceatmosphere fluxes (Slemr et al. 2011; Soerensen et al. 2012). Others have shown that declining point-source emissions of divalent $\mathrm{Hg}\left(\mathrm{Hg}^{\mathrm{II}}\right)$ in the northern hemisphere and from commercial products (Horowitz et al. 2014) were sufficient to reproduce observed declining trends in TGM from 1995 to present (Zhang et al. 2016d). TGM concentrations have decreased at lower rates in parts of the Arctic (approximately 0 to $-0.2 \%$ per year) (Cole et al. 2013). Several studies have suggested that the recent reversal in global TGM trends in China and India are due to increasing emissions from coal-fired power plants in addition to artisanal and small-scale gold mining (ASGM) activity (Slemr et al. 2014; Martin et al. 2017; Streets et al. 2017). At Cape Point in South Africa, TGM has increased during the last decade, although a clear explanation for this trend is lacking (Martin et al. 2017).

The global atmospheric $\mathrm{Hg}$ reservoir is estimated to be between 4400 and $5300 \mathrm{Mg}$, and is enriched by more than an order of magnitude relative to natural levels and by approximately three- to fivefold relative to 1850 levels (Amos et al. 2013; Engstrom et al. 2014; Horowitz et al. 2017; Streets et al. 2017). The anthropogenic contribution to atmospheric $\mathrm{Hg}$ has been inferred from observed $\mathrm{Hg}$ deposition in polar firn air, peat bogs, and lake sediments, all of which reveal large-scale impacts of anthropogenic emissions, particularly in the second half of the twentieth century (Biester et al. 2007; Faïn et al. 2009; Farmer et al. 2009; Outridge et al. 2011; Goodsite et al. 2013; Engstrom et al. 2014; Amos et al. 2015; Blais et al. 2015; Drevnick et al. 2016). Combining deposition records with $\mathrm{Hg}$ stable isotope analysis now allows differentiation between atmospheric $\mathrm{Hg}^{\mathrm{II}}$ and $\mathrm{Hg}^{0}$ deposition, and reconstruction of past $\mathrm{Hg}^{0}$ levels (Enrico et al. 2016, 2017). Enrico et al. (2017) suggest that the maximum twentieth-century atmospheric $\mathrm{Hg}^{0}$ concentration was 15 times larger than 


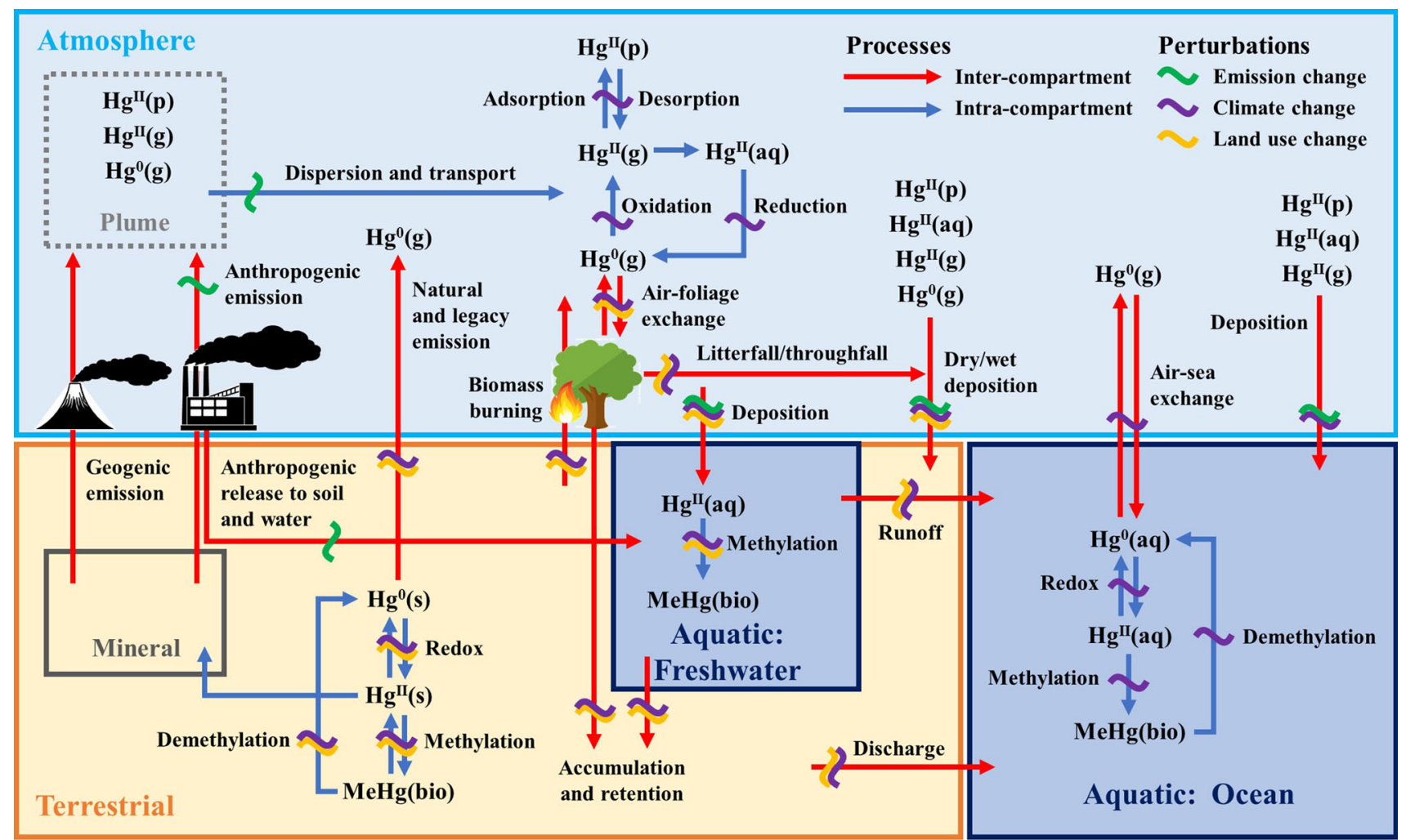

Fig. 2 Critical processes of global importance for $\mathrm{Hg}$ cycling, including fluxes between major environmental compartments. Perturbations of $\mathrm{Hg}$ processes and fluxes show anticipated impacts due to changes in emission, climate, and land use. A detailed discussion of the relevant processes is found in the "Recent advances in understanding critical Hg cycling processes of global importance" section, and major disturbances to global $\mathrm{Hg}$ cycling are discussed in the "Anticipated impacts from human and natural perturbations, including emission changes and climate change, on global Hg cycling" section

natural background at various locations, which agrees well with modeling analyses by Amos et al. (2015). Reconstructions suggest that historical atmospheric $\mathrm{Hg}^{0}$ concentrations peaked around 1970 at $3-4 \mathrm{ng} / \mathrm{m}^{3}$ and then declined to the current levels of $1.3-1.6 \mathrm{ng} / \mathrm{m}^{3}$ (Faïn et al. 2009; Enrico et al. 2017), consistent with atmospheric $\mathrm{Hg}^{0}$ concentration measurements of the last few decades. Lake sediment archives, reflecting total atmospheric Hg deposition, show similar time trends, with maximum $\mathrm{Hg}$ accumulation rates around 1970-1990 (Engstrom et al. 2014; Amos et al. 2015; Drevnick et al. 2016).

Direct anthropogenic $\mathrm{Hg}$ emissions account for approximately $30 \%$ of total annual inputs (i.e., total anthropogenic and natural emissions plus re-emission) to the atmosphere (Pirrone et al. 2010; UNEP 2013; Streets et al. 2017). While several different emission inventories exist for the present day, few are comparable across the past decades (Muntean et al. 2014) or address all-time human emissions (Streets et al. 2011; Horowitz et al. 2014; Streets et al. 2017). Global anthropogenic Hg emissions have been estimated at approximately $2000 \mathrm{Mg}$ /year by most studies (AMAP/UNEP 2008, 2013; Pacyna et al.
2010; Pirrone et al. 2010; Streets et al. 2011) except for one that reported a lower estimate (EDGARv4) of $1287 \mathrm{Mg} /$ year (Muntean et al. 2014). While reference years of studies are within a common period of 2005-2010, the sectoral distributions among some studies are inconsistent. The Arctic Monitoring and Assessment Programme and United Nations Environment Programme (AMAP/UNEP) (2008) and studies by Pacyna et al. (2010), Pirrone et al. (2010), and Streets et al. (2011) found stationary fossil fuel combustion (SFFC), mainly coal combustion, to be the leading source of $\mathrm{Hg}$ (800-900 Mg/year), followed by ASGM (400 Mg/year). By assuming a higher activity level of unregulated and illegal ASGM in some countries, UNEP's (2013) global $\mathrm{Hg}$ assessment (AMAP/UNEP 2013) estimated ASGM emissions of more than $700 \mathrm{Mg} /$ year. SFFC accounted for less than $500 \mathrm{Mg} /$ year of $\mathrm{Hg}$ in the UNEP inventory, while the EDGARv4 inventory (Muntean et al. 2014) estimated lower contributions from SFFC and ASGM. Given the global importance of ASGM releases, this source warrants further constraints. Nationallevel emission inventories rely on local field emission tests, with an increasing amount of data emerging from newly 
industrialized countries. For example, Zhang et al. (2015a) estimated anthropogenic $\mathrm{Hg}$ emissions in China to be $538 \mathrm{Mg}$ for 2010, somewhat lower than a previous estimate of $609 \mathrm{Mg} /$ year (Pirrone et al. 2010). The discrepancy was attributed to better $\mathrm{Hg}$ removal efficiencies of air pollution control devices for nonferrous metal smelting (Wang et al. 2010; Zhang et al. 2012). Emissions in India were recently estimated at approximately $240 \mathrm{Mg} /$ year (Pirrone et al. 2010; Burger Chakraborty et al. 2013). National anthropogenic $\mathrm{Hg}$ emission estimates are available for several other countries (e.g., Kim et al. 2010; Masekoameng et al. 2010; Nansai et al. 2012; Nelson et al. 2012; US EPA 2015). As per the UNEP emission inventory, the eight highest emitting countries are (in order) China, India, Indonesia, Columbia, South Africa, Russia, Ghana, and the U.S. These countries emit a total of $1095 \mathrm{Mg} /$ year of $\mathrm{Hg}$, or $56 \%$ of the global anthropogenic $\mathrm{Hg}$ emissions, to the atmosphere (AMAP/UNEP 2013; UNEP 2013). More accurate emission inventories are expected in the future, as parties of the UNEP Minamata Convention on Hg improve national $\mathrm{Hg}$ use and emission inventories.

Uncertainties remain in global anthropogenic $\mathrm{Hg}$ emission inventories, mainly because of a lack of local field test data for key sectors such as cement production, iron and steel production, waste incineration, and gold production, and a lack of accurate activity-level data for ASGM and intentional $\mathrm{Hg}$ use. Horowitz et al. (2014) found that more than $400 \mathrm{Mg} /$ year of atmospheric $\mathrm{Hg}$ emission was from the intentional use of $\mathrm{Hg}$ in products and processes (excluding gold production), previously unaccounted for in inventories. Top-down constraints and inverse modeling from atmospheric observations are currently being explored as additional tools to better constrain emissions (Song et al. 2015, 2016; Denzler et al. 2017).

$\mathrm{Hg}$ speciation profiles of emissions are crucial to assess the environmental impacts of atmospheric emissions (Zhang et al. 2016b). Streets et al. (2005) reported overall $\mathrm{Hg}^{0}: \mathrm{Hg}_{\text {gas }}^{\mathrm{II}}: \mathrm{Hg}_{\text {particulate }}^{\text {II }}$ ratios of 20:78:2 and 80:15:5 for Chinese coal-fired power plants (CFPPs) and cement plants (CPs), respectively, based on North American and European field test data. A recent study by Zhang et al. (2015a) updated the speciation profiles to 79:21:0 and 34:65:1 for Chinese CFPPs and CPs, respectively, based on onsite measurements. Such changes in speciation profiles for large point sources lead to large variations in $\mathrm{Hg}$ transport distances and local deposition fluxes.

$\mathrm{Hg}^{0}$ oxidation to $\mathrm{Hg}^{\mathrm{II}}$ is considered a key step in removing $\mathrm{Hg}$ from the atmosphere (Selin et al. 2008; Lyman and Jaffe 2011; Subir et al. 2011), although increasing evidence shows that oxidized $\mathrm{Hg}^{\mathrm{II}}$ deposition is dominant only in oceans, while $\mathrm{Hg}^{0}$ deposition is dominant in many terrestrial ecosystems (see below). A recent controversy has arisen around the techniques and artifacts in measuring atmospheric $\mathrm{Hg}$ oxidation and atmospheric $\mathrm{Hg}^{\mathrm{II}}$ concentrations. We refer to published reviews on atmospheric $\mathrm{Hg}$ and $\mathrm{Hg}^{\mathrm{II}}$ measurement methodologies (Lyman et al. 2010b; McClure et al. 2014a, b; Jaffe et al. 2014; Gustin et al. 2015; Angot et al. 2016; Mao et al. 2016; Marusczak et al. 2017). Earlier work suggested a primary role for the oxidants $\mathrm{OH}$ and $\mathrm{O}_{3}$ in $\mathrm{Hg}^{0}$ oxidation, but observations and theoretical calculations now suggest that the $\mathrm{Br}$ radical is likely the dominant oxidant (Hynes et al. 2009; Gratz et al. 2015; Shah et al. 2016). Current thinking is that the mechanism is a two-step process, where $\mathrm{Hg}^{0}$ reacts with the $\mathrm{Br}$ radical to form $\mathrm{HgBr}$, and $\mathrm{HgBr}$ reacts with multiple potential oxidants $\left(\mathrm{Br}, \mathrm{I}, \mathrm{OH}, \mathrm{BrO}, \mathrm{IO}, \mathrm{NO}_{2}\right.$, etc.) to generate different $\mathrm{Hg}^{\mathrm{II}}$ species (Goodsite et al. 2004; Dibble et al. 2012; Wang et al. 2014; Ye et al. 2016; Horowitz et al. 2017; Jiao and Dibble 2017). Recent aircraft observations showed substantial atmospheric $\mathrm{Hg}^{\mathrm{II}}$ concentrations and detectable $\mathrm{BrO}$ in the subtropics, suggesting that subtropical anticyclones are significant global $\mathrm{Hg}^{\mathrm{II}}$ sources (Gratz et al. 2015; Shah et al. 2016). Photolytic formation of halogen radicals and $\mathrm{Hg}$ oxidation may occur at low light conditions, and recent Antarctic wintertime $\mathrm{Hg}$ oxidation may suggest a possible dark oxidation process (Nerentorp Mastromonaco et al. 2016). Hg oxidation chemistry has recently been updated in the GEOSChem model by Horowitz et al. (2017), which describes incloud $\mathrm{Hg}^{\text {II }}$ photoreduction as potentially important in $\mathrm{Hg}$ redox chemistry (Holmes et al. 2010; Horowitz et al. 2017). A recent model comparison (Travnikov et al. 2017), not including the updated chemistry of Horowitz et al., showed that models with a $\mathrm{Br}$ oxidation mechanism reproduced the observed near-surface seasonal variations in the $\mathrm{Hg}^{\text {II }}$ fraction, but did not capture seasonal variations in wet deposition observed at monitoring sites in North America and Europe. These findings suggest that more complex $\mathrm{Hg}$ oxidation chemistry and multi-oxidation pathways may be occurring in different regions of the atmosphere.

\section{Terrestrial}

In the terrestrial environment, the largest $\mathrm{Hg}$ pools are located in soils (Grigal 2003; Obrist 2012). Using global soil carbon inventories, $\mathrm{Hg}$ pools have been estimated at $300 \mathrm{Gg}$ (Hararuk et al. 2013) and $240 \mathrm{Gg}$ (Smith-Downey et al. 2010). The latter study estimated a $20 \%$ modern-day increase in overall soil storage and an even greater increase of $\mathrm{Hg}$ associated with the labile soil carbon fraction (Smith-Downey et al. 2010). Newer simulations using additional observational constraints (Streets et al. 2011; Horowitz et al. 2014) estimate higher present-day organic soil $\mathrm{Hg}$ pools (250-1000 Gg with a best estimate of 500 $\mathrm{Gg}$ ) and propose that anthropogenic activities have doubled the Hg stored in organic soils (Amos et al. 2013, 2015). Hg 
in organic-rich upper soils is predominantly from atmospheric deposition (Grigal et al. 2000; Schwesig and Matzner 2000; Guedron et al. 2006; Peña-Rodríguez et al. 2012; Demers et al. 2013; Peña-Rodríguez et al. 2014; Jiskra et al. 2015; Enrico et al. 2016; Zheng et al. 2016; Obrist et al. 2017; Wang et al. 2017). Atmospheric Hg deposits are retained in humus-rich upper soils and bound to organic matter (Meili 1991; Grigal 2003; Obrist et al. 2011; Jiskra et al. 2015). In mineral horizons, a significant component of $\mathrm{Hg}$ also stems from release from natural geologic sources.

New spatial soil datasets demonstrate that landscape $\mathrm{Hg}$ distribution is correlated to soil organic matter, latitude, annual precipitation, leaf area index, and vegetation greenness (Obrist et al. 2011; Richardson et al. 2013; Navrátil et al. 2014, 2016; Obrist et al. 2016). Obrist et al. (2016) explained soil $\mathrm{Hg}$ variability across 1911 sites in the western U.S., largely by vegetation patterns, with high soil $\mathrm{Hg}$ accumulation in productive forests and 2.5 times lower soil concentrations in unproductive deserts and scrublands. Such patterns are due to a dominance of plant-funneled atmospheric $\mathrm{Hg}^{0}$ deposition in many terrestrial ecosystems (see below), or by higher re-emission of $\mathrm{Hg}$ from deserts compared to forests (Eckley et al. 2016). Soil Hg accumulation and retention, however, are also determined by soil morphology and genesis as well as soil properties, including soil organic matter stability, content, texture, and pH (Obrist et al. 2011; Richardson and Friedland 2015; Navrátil et al. 2016). Landscape gradients with the highest inorganic $\mathrm{Hg}$ concentrations in forested watersheds have also been reported in river and lake sediments (Fleck et al. 2016), highlighting strong connectivity between upland $\mathrm{Hg}$ deposition and aquatic loading. This is consistent with earlier studies that linked high biological $\mathrm{Hg}$ hotspots in the eastern U.S. to watersheds with high forest densities (Driscoll et al. 2007).

Elevation gradients in $\mathrm{Hg}$, largely associated with shifts in vegetation type, have also been observed, with vegetation and organic soil $\mathrm{Hg}$ concentrations increasing by up to fourfold with increasing elevation (Zhang et al. 2013; Townsend et al. 2014; Blackwell and Driscoll 2015; Wang et al. 2017). Blackwell and Driscoll (2015) reported a shift in deposition patterns along an alpine forest gradient, from deposition dominated by litterfall (i.e., uptake of $\mathrm{Hg}$ by plant foliage and transfer to ecosystems after senescence/ leaf shedding) to throughfall deposition (i.e., $\mathrm{Hg}$ uptake to plant surfaces and wash-off by precipitation) and deposition via cloudwater. They also noted that cloudwater accounted for up to $71 \%$ of total deposition at the highest altitudes. $\mathrm{Hg}$ stable isotope studies are inconsistent, reporting both higher contributions of $\mathrm{Hg}^{\mathrm{II}}$ at high-elevation sites (Zhang et al. 2013; Zheng et al. 2016) and lower contributions of $\mathrm{Hg}^{\mathrm{II}}$ with increasing altitude (Wang et al. 2017).

\section{Aquatic}

Oceans contain a substantial fraction of the global $\mathrm{Hg}$ reservoir and strongly affect atmospheric concentrations through air-sea exchange (Soerensen et al. 2010; Zhang et al. 2015b). Sunderland and Mason (2007) estimated the total ocean $\mathrm{Hg}$ to be $350 \mathrm{Gg}$ with a $90 \%$ confidence limit of 270-450 Gg. More recent work (Lamborg et al. 2014; Zhang et al. 2015b) suggests a reservoir of 260-280 Gg. Lamborg et al. (2014) estimated the upper ocean (top $1000 \mathrm{~m}$ ) reservoir, based on observations from the GEOTRACES cruise series, to be $63 \mathrm{Mg}$, which is on the low end of the range reported by Sunderland and Mason (2007) (63-120 Mg; $90 \%$ confidence interval), and may indicate either declining concentrations in some basins or improvements in analytical techniques (Lamborg et al. 2012). In the pelagic marine environment, trends in total $\mathrm{Hg}(\mathrm{THg})$ concentration are difficult to infer because of large inter-laboratory variability in measurements (Lamborg et al. 2012). Concentrations in the North Atlantic appear to be declining during the last several decades, from mean vertical profile concentrations of above $5 \mathrm{pM}$ in the 1990s to consistently below $1 \mathrm{pM}$ on recent cruises (Bowman et al. 2016). In the North Pacific, however, Sunderland et al. (2009) suggest that the THg concentration in the North Pacific Intermediate Water (NPIW) mass has increased since the mid-1980s due to enhanced atmospheric deposition from the Asian continent. Other cruises that sampled different locations (Hammerschmidt and Bowman 2012; Munson et al. 2015) did not see statistically different THg concentrations than those measured on earlier cruises, but current data coverage is sparse.

In freshwater ecosystems, predominant $\mathrm{Hg}$ sources include direct release from $\mathrm{Hg}$-containing effluents, river runoff that contains atmospheric $\mathrm{Hg}$ deposits that accumulated in terrestrial environments, and direct atmospheric $\mathrm{Hg}$ deposition. The latter is particularly important in lakes with large surface area-to-volume ratios and small catchment-tolake surface areas. The relative importance of atmospheric and watershed $\mathrm{Hg}$ sources varies [see the "Atmosphereaquatic interactions" section and Hsu-Kim et al. (2018)] depending on the degree of development and land use change, hydrology, and dissolved organic carbon (DOC) content and composition (Engstrom and Swain 1997; Knightes et al. 2009; Lepak et al. 2015). Kocman et al. (2017) recently developed a first inventory of $\mathrm{Hg}$ inputs to freshwater ecosystems and estimated that $800-2200 \mathrm{Mg} /$ year of $\mathrm{Hg}$ enters freshwater ecosystems. This is lower than the amount of $\mathrm{Hg}$ entering coastal ecosystems estimated by Amos et al. (2014) (5500 $\pm 2700 \mathrm{Mg} /$ year), in part because 
it does not include natural mobilization from terrestrial ecosystems. Earlier estimates of global riverine $\mathrm{Hg}$ release to the ocean were between 1000 and $2000 \mathrm{Mg} /$ year (Cossa et al. 1997; Sunderland and Mason 2007). ASGM is the largest direct $\mathrm{Hg}$ source globally to both land and water (approximately $880 \mathrm{Mg} /$ year); although the proportion released to aquatic ecosystems is not certain, it is estimated to be 50\% (Kocman et al. 2017). Streets et al. (2017) suggest that approximately $40 \%$ of combined $\mathrm{Hg}$ releases to land and water globally are sequestered at the release site rather than traveling in rivers to the ocean. In India and China, industrial $\mathrm{Hg}$ sources (from the chlor-alkali industry, $\mathrm{Hg}$ and large-scale gold production, nonferrous metal production, and Hg-containing waste) release approximately $86 \mathrm{Mg} / \mathrm{year}$ to lakes and rivers, accounting for $51 \%$ of global aquatic releases from these sources (Kocman et al. 2017).

Methylmercury $(\mathrm{MeHg})$ production is a critical process that occurs within aquatic ecosystems. The largest source of $\mathrm{MeHg}$ to freshwater lakes and wetlands is in situ microbial production, with surface sediments producing larger amounts than the water column. However, the relative contributions of water column versus sediment productions depend on specific characteristics of lakes such as stratification, depth of the anoxic hypolimnion, and organic carbon content of sediments. The activity of methylating microbes is controlled by temperature, redox conditions, $\mathrm{pH}$, and the presence of suitable electron donors (e.g., organic carbon) and acceptors (e.g., sulfate, $\mathrm{Fe}^{\mathrm{III}}$, methane). The primary controls on inorganic $\mathrm{Hg}$ bioavailability include DOC, sulfur, and $\mathrm{Hg}^{\mathrm{II}}$ concentrations and speciation (Benoit et al. 1999; Boening 2000; Ullrich et al. 2001; Gilmour et al. 2013; Hsu-Kim et al. 2013). A breakthrough paper by Parks et al. (2013) identified a two-gene cluster ( $h g c A$ and $h g c B)$ in microbes involved in $\mathrm{Hg}$ methylation. The $h g c A$ gene encodes a putative corrinoid protein capable of transferring a methyl group to $\mathrm{Hg}^{\mathrm{II}}$, and the $\mathrm{HgcB}$ protein returns $\mathrm{HgcA}$ to a redox state that enables it to receive a new methyl group. Subsequent work identified these genes in many organisms, including sulfate and iron-reducing bacteria and methanogens (Gilmour et al. 2013; Yu et al. 2013; Podar et al. 2015). Several studies have developed $h g c A$ probes to screen aquatic sediments for $\mathrm{Hg}$-methylating microorganisms (Bae et al. 2014; Schaefer et al. 2014; Bravo et al. 2015; Du et al. 2017) and to demonstrate that different methylating microbes inhabit various niches, such as regions of wetlands with varying sulfate concentrations (Bae et al. 2014; Schaefer et al. 2014). Recent development of a broad range of probes spanning all known $h g c A B$ genes (Christensen et al. 2016) may allow future quantification of the methylating potential in environmental samples.
One conundrum that remains is how to explain high levels of $\mathrm{MeHg}$ in marine seawater where $\mathrm{MeHg}$ production is still poorly understood. Gionfriddo et al. (2016) found that the micro-aerophilic, nitrite-oxidizing bacterium Nitrospina, present in Antarctic sea ice and brine, contains genes that are slight rearrangements of the $h_{g c A B}$ genes, suggesting that diverse microbial communities may be capable of methylation. Fitzgerald et al. (2007) suggested that most marine $\mathrm{MeHg}$ is produced in ocean margin sediments, but a variety of studies across most major ocean basins have since produced strong evidence for water column MeHg production (Cossa et al. 2009; Sunderland et al. 2009; Heimbürger et al. 2010; Cossa et al. 2011; Lehnherr et al. 2011; Blum et al. 2013). In the last several years, the abundance of ocean water concentration measurements has increased dramatically with new data from the North Pacific (Kim et al. 2017); North Atlantic (Bowman et al. 2014); Equatorial, South Atlantic, and Pacific (Munson et al. 2015; Bowman et al. 2016); Arctic (Heimburger et al. 2015); and Antarctic Oceans (Gionfriddo et al. 2016). In the coastal marine environment, Schartup et al. (2015) used enriched $\mathrm{Hg}$ isotope incubation to detect active $\mathrm{Hg}$ methylation for the first time in oxic estuarine seawater. Methylation was facilitated by the presence of labile terrestrial DOC and a shift in ionic strength and microbial activity that accompanies the transition into saline waters in estuaries. Similarly, Ortiz et al. (2015) measured active methylation in laboratory experiments with marine snow aggregates.

Marine species are responsible for a large fraction of human exposure to MeHg; for example, Sunderland (2007) found that for the U.S. more than $90 \%$ of MeHg exposure is from marine and estuarine species. Thus, understanding $\mathrm{MeHg}$ dynamics in marine environments is particularly important for public health (Gribble et al. 2016). Advances have been made in understanding $\mathrm{MeHg}$ uptake to aquatic food webs (see Eagles-Smith et al. 2018). The photochemical demethylation of $\mathrm{MeHg}$ has been shown experimentally to result in a large enrichment of odd-massnumbered $\mathrm{Hg}$ isotopes $\left(\Delta^{199} \mathrm{Hg}\right.$; Fig. 3, Box 1) in the residual $\mathrm{MeHg}$ pool that accumulated through the food web (Bergquist and Blum 2007). Odd-mass-independent fractionation (MIF) anomalies in aquatic organisms were used as source tracers to distinguish between $\mathrm{MeHg}$ derived from sediments with small odd-MIF isotopes and $\mathrm{MeHg}$ from the open ocean with large odd-MIF isotopes (Senn et al. 2010; Blum et al. 2013). Odd-MIF anomalies in biota have been hypothesized to serve as source tracers and as a proxy for ecological parameters such as foraging depth; for example, the largest odd-MIF anomalies are found in fish feeding in surface waters where photochemical demethylation is most active (Blum et al. 2013). The extent of oddMIF anomaly is reduced in aquatic organisms where light 


\section{Hg stable Isotope systematics}
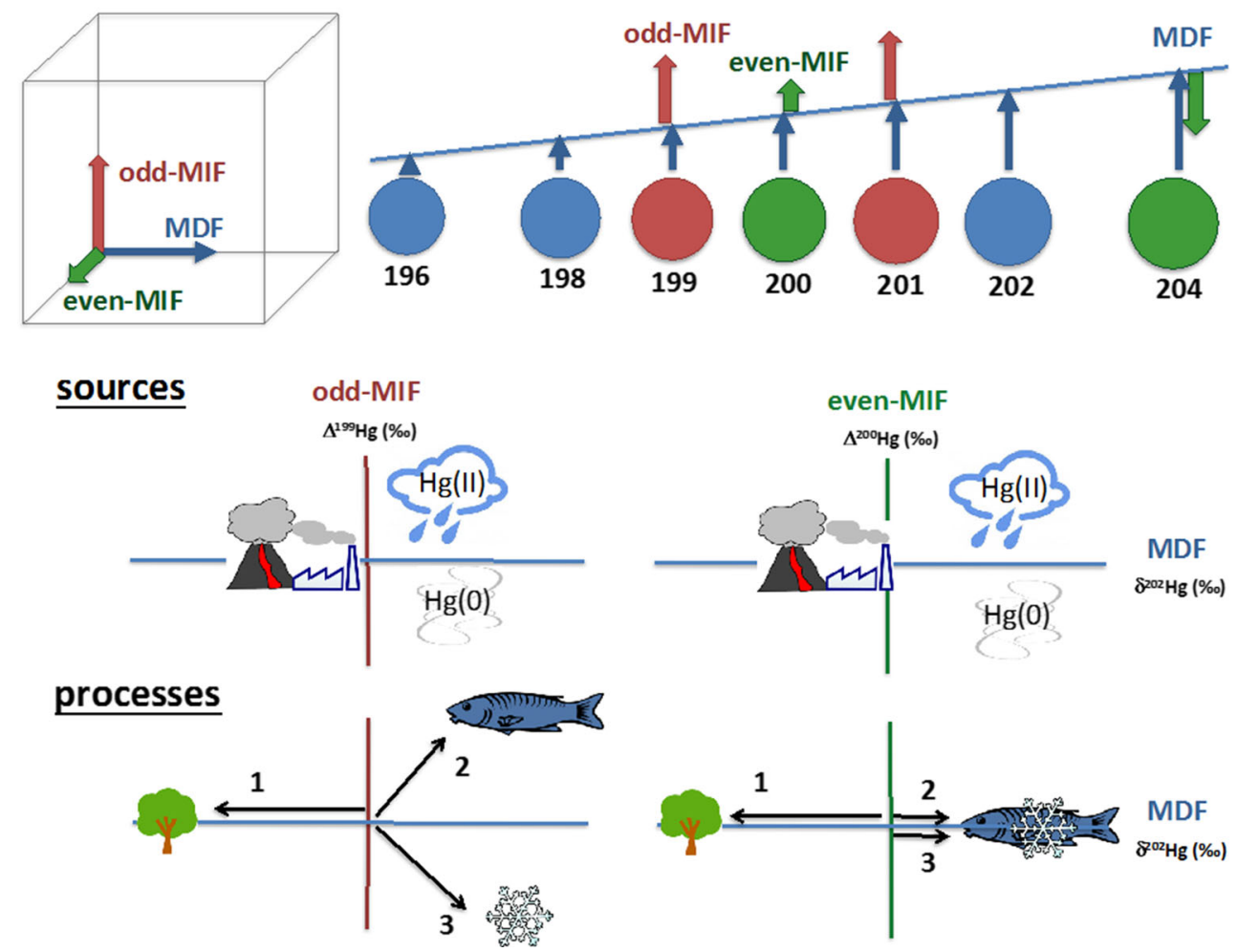

Fig. 3 Simplified schematic of Hg stable isotope systematics adapted from Wiederhold et al. (2010). The seven Hg stable isotopes undergo mass-dependent fractionation (MDF) proportional to their atomic mass. Anomalies from the MDF line are defined as mass-independent fractionation (MIF) of the odd-mass-number ${ }^{199} \mathrm{Hg}$ and ${ }^{201} \mathrm{Hg}$ (odd-MIF) and even-mass-number ${ }^{200} \mathrm{Hg}$ and ${ }^{204} \mathrm{Hg}$ (even-MIF) isotopes. MDF, odd-MIF, and even-MIF signatures serve as 3D tracers for fingerprinting different $\mathrm{Hg}$ sources of natural and anthropogenic emissions, or atmospheric oxidized $\left(\mathrm{Hg}^{\mathrm{II}}\right)$ and elemental $\left(\mathrm{Hg}^{0}\right)$ pools. Examples of processes with large isotope fractionation factors in the environment include (1) foliar uptake of $\mathrm{Hg}^{0}$ from the atmosphere (Demers et al. 2013; Enrico et al. 2016; Yu et al. 2016); (2) photochemical demethylation of MeHg in waters (Bergquist and Blum 2007); and (3) photochemical reduction of $\mathrm{Hg}^{\mathrm{II}}$ to $\mathrm{Hg}^{0}$ in snow (Sherman et al. 2010)

penetration in the aquatic water column is inhibited [e.g., by sea ice (Point et al. 2011; Masbou et al. 2015)] or with high DOC (Sherman and Blum 2013). Thus, odd-MIF anomalies can track changes in climatological/environmental parameters such as sea-ice cover. Field measurements and experimental data suggest that DOC controls $\mathrm{MeHg}$ availability for uptake in freshwater. French et al. (2014) observed a water column DOC threshold of 8.6-8.8 mg/L, above which $\mathrm{MeHg}$ uptake was inhibited in Arctic lakes, while Jonsson et al. (2014) showed that in estuarine microcosms DOC-bound $\mathrm{MeHg}$ was 5-250 times more available for bioaccumulation into lower food web organisms than newly produced $\mathrm{MeHg}$.

\section{Atmosphere-terrestrial interactions}

Large uncertainties in terrestrial $\mathrm{Hg}^{0}$ sinks and source strengths, particularly over background areas and vegetated areas, make atmosphere-terrestrial interactions one of least constrained processes in the global $\mathrm{Hg}$ cycle. Major emissions from terrestrial ecosystems include biomass burning and volatilization of $\mathrm{Hg}^{0}$ from natural and $\mathrm{Hg}$ enriched soils, while deposition from the atmosphere includes dry $\mathrm{Hg}^{0}$ deposition to plants and soils and wet $\mathrm{Hg}^{\mathrm{II}}$ deposition.

Recent global atmospheric models have reported global biomass burning emissions of $\mathrm{Hg}$ between 210 and $680 \mathrm{Mg} /$ year (Amos et al. 2014; De Simone et al. 2015; Song et al. 2016). Webster et al. (2016) recently provided an update on atmospheric $\mathrm{Hg}$ emissions from western U.S. wildfires and suggest a fivefold lower total $(3.1 \pm 1.9 \mathrm{Mg} /$ year across 11 states) compared to previous estimates (14.7 Mg/year) (Wiedinmyer and Friedli 2007). The lower $\mathrm{Hg}$ emission estimates from Webster et al. are attributed mainly to the inclusion of fire severity and the notion that low-severity burns (52\% of wildfires) result in lower soil heating and less $\mathrm{Hg}$ emissions. Other studies also found that $\mathrm{Hg}$ losses are related to fire intensity (Mitchell et al. 
Box 1 Use of stable isotopes to constrain $\mathrm{Hg}$ sources and processes

The seven stable isotopes of $\mathrm{Hg}(196,198,199,200,201,202$, and 204) are subject to different mass-dependent (MDF) and mass-independent (MIF) isotope fractionation mechanisms. The isotopic signature of $\mathrm{Hg}$ in a sample carries information on its initial source and the transformation processes it underwent. Here we provide a simplified three-dimensional view of $\mathrm{Hg}$ stable isotope systematics and focus on exemplary processes and sources that have pronounced identifiable effects on $\mathrm{Hg}$ isotope signatures in environmental samples. For a more comprehensive introduction to $\mathrm{Hg}$ isotope fractionation and a compilation of $\mathrm{Hg}$ isotope variation in natural samples, we refer to the reviews of Blum et al. (2014) and Blum and Johnson (2017).

$M D F$ (mass-dependent fractionation) is reported as $\delta^{202} \mathrm{Hg}$ in the "small delta" notation, representing the ${ }^{202 / 198} \mathrm{Hg}$ ratio of a sample relative to the NIST SRM3133 international standard as defined by Blum and Bergquist (2007). Primary natural and anthropogenic Hg emission sources are generally associated with small negative $\delta^{202} \mathrm{Hg}$ signatures, whereas atmospheric $\mathrm{Hg}$ pools have positive $\delta^{202} \mathrm{Hg}$ values (Blum et al. 2014; Sun et al. 2016b). All biotic and abiotic transformation processes enrich $\mathrm{Hg}$ stable isotopes to different extents by MDF. One of the largest MDF fractionations observed is associated with preferential uptake of light atmospheric $\mathrm{Hg}^{0}$ by foliage (arrow 1 in Fig. 3 ) (Demers et al. 2013; Enrico et al. 2016; Yu et al. 2016).

Odd-MIF (mass-independent fractionation of odd-mass-number $\mathrm{Hg}$ isotopes) is reported as $\Delta^{199} \mathrm{Hg}$ and $\Delta^{201} \mathrm{Hg}$ in the "capital delta" notation, representing the anomalies of the ${ }^{199 / 198} \mathrm{Hg}$ and ${ }^{201 / 198} \mathrm{Hg}$ ratios from the MDF line, respectively (Blum and Bergquist 2007). Two independent mechanisms have been experimentally shown to cause odd-MIF: (1) magnetic isotope effects (MIE) (Buchachenko 2001, 2009) and (2) nuclear volume fractionation (NVF) (Bigeleisen 1996; Schauble 2007). Primary Hg sources are generally associated with circum-zero odd-MIF (Sun et al. 2016b). Largest odd-MIF signatures are associated with MIE by photochemical reactions, whereas odd-MIF associated with NVF (identifiable by a different $\Delta^{199} \mathrm{Hg} / \Delta^{201} \mathrm{Hg}$ ratio) is relatively small. Photochemical demethylation of MeHg to $\mathrm{Hg}^{0}$ has been shown to cause large odd-MIF, leading to an enrichment of odd-mass $\mathrm{Hg}$ isotopes in the residual MeHg that is preserved along the aquatic food chain (arrow 2 in Fig. 3) (Bergquist and Blum 2007). Photoreduction of $\mathrm{Hg}^{\mathrm{II}}$ complexes in snow was shown to lead to large depletions of odd-mass isotopes in residual snow (arrow 3 in Fig. 3) (Sherman et al. 2010).

Even-MIF (mass-independent fractionation of even-mass-number $\mathrm{Hg}$ isotopes) is reported as $\Delta^{200} \mathrm{Hg}$ and $\Delta^{204} \mathrm{Hg}$, representing anomalies of the ${ }^{200 / 198} \mathrm{Hg}$ and ${ }^{204 / 198} \mathrm{Hg}$ ratios from the MDF line (Blum and Bergquist 2007). The potential mechanisms causing even-MIF have not been identified yet, but are possibly related to oxidation of $\mathrm{Hg}^{0}$ by halogen radicals in the atmosphere (Sun et al. 2016a). $\mathrm{Hg}^{\mathrm{II}}$ in precipitation, representing atmospheric gaseous and aerosol $\mathrm{Hg}^{\mathrm{II}}$, is consistently enriched in positive anomalies of $\Delta^{200} \mathrm{Hg}$ (and concurrent negative $\Delta^{204} \mathrm{Hg}$ ) (Gratz et al. 2010; Chen et al. 2012; Sherman et al. 2012; Demers et al. 2013; Enrico et al. 2016). The complementary pool of atmospheric $\mathrm{Hg}^{0}$ is enriched in negative $\Delta^{200} \mathrm{Hg}$ (and concurrent positive $\Delta^{204} \mathrm{Hg}$ ) anomalies (Gratz et al. 2010; Demers et al. 2013, 2015, Enrico et al. 2016; Obrist et al. 2017). Note that the possible mechanisms for even-MIF are not necessarily associated with the ${ }^{200} \mathrm{Hg}$ and ${ }^{204} \mathrm{Hg}$ isotopes only and may also affect the ${ }^{202 / 198} \mathrm{Hg}$ ratio that is used for normalization.

2012; Kolka et al. 2017). Wildfire studies consistently show that fires mobilize Hg primarily from biomass, litter, and organic soils (Friedli et al. 2001, 2003; Engle et al. 2006; Biswas et al. 2007; Obrist 2007; Wiedinmyer and Friedli 2007; Biswas et al. 2008; Burke et al. 2010; Woodruff and Cannon 2010), although Hg released from upper mineral soils can comprise up to $10 \%$ of total emissions (Biswas et al. 2007; Burke et al. 2010; Melendez-Perez et al. 2014). Significant post-fire soil evasion of $\mathrm{Hg}^{0}$ has been reported to occur years after fires, leading to an additional 50\% in Hg emissions (Melendez-Perez et al. 2014), an effect which is not included in wildfire emission estimates.

A relatively well-constrained component of the atmosphere-terrestrial exchange is wet deposition of $\mathrm{Hg}^{\mathrm{II}}$, at least over land where extensive monitoring networks exist, including the Mercury Deposition Network (MDN) for the U.S. and Canada (Prestbo and Gay 2009; Weiss-Penzias et al. 2016; Sprovieri et al. 2017), the European Monitoring and Evaluation Programme (EMEP) for Europe (Tørseth et al. 2012), and a new Asia-Pacific Mercury Monitoring Network (2017) and the Global Mercury Observation System (GMOS) for other parts of the world. At background sites, mean atmospheric $\mathrm{Hg}$ wet deposition globally decreased from $10-15 \mu \mathrm{g} / \mathrm{m}^{2} /$ year in the early 1990 s to the current level of $5-10 \mu \mathrm{g} / \mathrm{m}^{2} /$ year (Zhang et al. 2016d). Declines in atmospheric $\mathrm{Hg}^{\mathrm{II}}$ wet deposition are reported from Europe and the U.S. with average deposition declines of $-1.5 \%$ per year and $-2.3 \%$ per year between 1990 and 2013, respectively (Zhang et al. 2016d), although increasing wet $\mathrm{Hg}^{\mathrm{II}}$ deposition has been reported in East Asia. Mean background $\mathrm{Hg}$ wet deposition fluxes in the northern hemisphere, the tropics, and the southern hemisphere are approximately $5-10,2-8$, and $1-5 \mu \mathrm{g} / \mathrm{m}^{2} /$ year, respectively (Prestbo and Gay 2009; Fu et al. 2016a; Sprovieri et al. 2016, 2017). There is, however, large spatial and temporal variability in wet $\mathrm{Hg}^{\mathrm{II}}$ deposition (Butler et al. 2008; Prestbo and Gay 2009; Risch et al. 2012b; Zhang and Jaeglé 2013; Cole et al. 2014; Muntean et al. 2014; Sprovieri et al. 2016).

Estimated median dry deposition fluxes of $\mathrm{Hg}_{\text {gaseous }}^{\mathrm{II}}$ and $\mathrm{Hg}_{\text {particulate }}^{\mathrm{II}}$ in Asia and North America are 10.7 and $6.1 \mu \mathrm{g} /$ $\mathrm{m}^{2} /$ year, respectively. A particular challenge with dry $\mathrm{Hg}^{\mathrm{II}}$ deposition is that measurements and modeling schemes have uncertainty factors greater than two (Wright et al. 2016), in addition to large measurement uncertainties (see the "Atmosphere" section). Atmospheric dry deposition flux measurements can be broadly divided into micrometeorological methods based on gradient measurements, dynamic gas flux chambers, and surrogate surface passive 
samplers, which have been more widely used in recent years (Lyman et al. 2009; Zhang et al. 2009; Lyman et al. 2010a; Gustin et al. 2011; Pirrone et al. 2013; Gustin et al. 2015; Huang and Gustin 2015). To model deposition, resistance approaches are used in chemical transport models that apply dry deposition velocities for $\mathrm{Hg}^{\mathrm{II}}$ and measured or estimated $\mathrm{Hg}^{\mathrm{II}}$ concentrations (Lin et al. 2006; Zhang et al. 2009). For simulations of net $\mathrm{Hg}^{0}$ deposition, bidirectional soil-vegetation-air exchange models are needed (Bash et al. 2007; Zhang et al. 2009); current models are not well constrained. Models have been used to estimate total $\mathrm{Hg}$ deposition compared with existing measurements and to attribute deposition to sources in the context of policy. Different models show similar global $\mathrm{Hg}$ deposition patterns, especially near source regions, and can reproduce major features of observed wet deposition (Travnikov et al. 2017). However, in some regions, there are substantial differences in simulated attributions of $\mathrm{Hg}$ deposition to local versus international sources.

Atmospheric $\mathrm{Hg}^{0}$ emissions from land surfaces was previously estimated between 1600 and $2900 \mathrm{Mg} /$ year (Lindberg et al. 2007; Selin et al. 2008; Smith-Downey et al. 2010), but more recent estimates are considerably lower at $607 \mathrm{Mg} /$ year (- 513 to $1353 \mathrm{Mg} /$ year) (Agnan et al. 2016). Estimates of large terrestrial $\mathrm{Hg}^{0}$ evasion, or remobilization of legacy $\mathrm{Hg}$ from previous depositions, are in part based on enriched isotope tracing studies that showed that $45-70 \%$ of applied labile $\mathrm{HgCl}_{2}$ was subject to atmospheric evasion (Hintelmann et al. 2002; Graydon et al. 2012). However, recent global data assimilations of $20+$ years of terrestrial $\mathrm{Hg}^{0}$ flux measurements (Agnan et al. 2016; Zhu et al. 2016) now show that in most of the world $\mathrm{Hg}^{0}$ evasion from background soils is generally low, particularly when soils are covered by litter or plants. In fact, many background soils also show periods of net $\mathrm{Hg}^{0}$ deposition (Gustin et al. 2000; Choi and Holsen 2009) with recent work showing net $\mathrm{Hg}^{0}$ deposition in $20 \%$ of measurements over bare soils and in $45 \%$ over covered soils (Agnan et al. 2016). On the other hand, Agnan et al. (2016) and Zhu et al. (2016) showed an increased importance of soil $\mathrm{Hg}^{0}$ emissions in areas with high atmospheric $\mathrm{Hg}$ exposures (such as East Asia), which according to Agnan et al. (2016) now accounts for $261 \mathrm{Mg} /$ year (range of $114-359 \mathrm{Mg} /$ year) of $\mathrm{Hg}^{0}$ emissions. They also estimated $\mathrm{Hg}^{0}$ evasions from naturally $\mathrm{Hg}$-enriched and contaminated areas $(217 \mathrm{Mg} /$ year, range of $202-258 \mathrm{Mg} /$ year) that were lower than previous estimates (Ericksen et al. 2006) but still the second largest terrestrial $\mathrm{Hg}^{0}$ source. Another terrestrial $\mathrm{Hg}^{0}$ source includes global croplands $(201 \mathrm{Mg}$ / year; range 195-208 Mg/year). When considering vegetation uptake of atmospheric $\mathrm{Hg}$, most terrestrial ecosystems turn into net atmospheric $\mathrm{Hg}^{0}$ sinks (see below). Recent global model simulations now reflect reduced soil $\mathrm{Hg}^{0}$ evasion (Amos et al. 2014, 2015); one global atmospheric model simulation (Song et al. 2016) showed reduced global soil evasions from 2200 to $1360 \mathrm{Mg} / \mathrm{year}$, which is still in the higher range based on flux measurements by Agnan et al. (2016).

Over land, $\mathrm{Hg}^{\mathrm{II}}$ deposition is minor compared to $\mathrm{Hg}^{0}$ deposition, and the dominant pathway of atmospheric deposition to terrestrial ecosystems is through litterfall. Globally, this deposition pathway is estimated at 1020-1230 Mg (Obrist 2007; Risch et al. 2012a; Fu et al. 2016a, b; Wang et al. 2016; Wright et al. 2016; Zhang et al. 2016c). In addition, throughfall deposition may contribute an additional $50 \%$ of litterfall deposition (Wang et al. 2016), which would result in a global deposition flux of approximately $560 \mathrm{Mg} /$ year, although this needs further observational confirmation. In addition, further plant depositions occur via woody tissues, including by tree blowdown (Mitchell et al. 2012). Given that $\mathrm{Hg}$ contained in woody biomass can exceed $\mathrm{Hg}$ contained in foliage biomass by $67-100 \%$ (Obrist et al. 2012; Yang et al. 2017), woody tissue deposition is likely an important, yet not well-constrained, source of deposition as well (Obrist 2007). Plant contributions (litterfall plus throughfall wet deposition) dominate deposition loads in forests globally (70-85\%), of which approximately $75 \%$ (with the exception of South American rainforests) is litterfall (Wang et al. 2016). Wright et al. (2016) and Wang et al. (2016) show large continental differences with high litterfall fluxes in the Amazon and in China that are greater than fivefold those in North America and Europe. This suggests that deposition fluxes decrease spatially from tropical to temperate/boreal regions, with $30 \%$ of total deposition in the temperate and boreal regions and $70 \%$ of total deposition in the tropical/subtropical regions. Unfortunately, there is a lack of plant and associated $\mathrm{Hg}$ litterfall and throughfall deposition data outside of forest ecosystems, such that estimates for global grasslands, savannas, and shrublands remain highly uncertain. $\mathrm{Hg}$ stable isotope approaches now suggest that $\mathrm{Hg}^{0}$ deposited via plants comprises the majority of $\mathrm{Hg}$ deposition to soils in central North America (57-94\%) (Demers et al. 2013; Zheng et al. 2016), Alaskan tundra soils (71\%) (Obrist et al. 2017), central European peat soils (79\%) (Enrico et al. 2016), boreal forest soils in North Sweden (90\%) (Jiskra et al. 2015), and high mountain soils in Tibet (Wang et al. 2017). This is likely also true for other areas of the world, for example, the tropics, where some of the highest litterfall $\mathrm{Hg}$ deposition is observed (Wang et al. 2016). Recent field studies also show evidence for an active $\mathrm{Hg}^{0}$ sink in soils (Sigler and Lee 2006; Moore and Castro 2012; Obrist et al. 2014, 2017) and possibly direct deposition of $\mathrm{Hg}^{0}$ to forest litter (Zheng et al. 2016). The finding that litterfall is the dominant terrestrial $\mathrm{Hg}^{0}$ source fundamentally reshapes our 
understanding of $\mathrm{Hg}$ deposition to terrestrial landscapes and $\mathrm{Hg}$ mobility, demonstrating the need for monitoring strategies to measure net ecosystem $\mathrm{Hg}^{0}$ deposition, including direct exchange/deposition measurements. The dominant role of foliar $\mathrm{Hg}^{0}$ uptake also results in a specific "terrestrial" $\mathrm{Hg}$ isotope signature that can be used to trace terrestrial contributions and transfer to aquatic ecosystems (Tsui et al. 2012; Kwon et al. 2015; Jiskra et al. 2017), aquatic biota (Li et al. 2016), and lake and ocean sediments (Grasby et al. 2015; Lepak et al. 2015; Enrico et al. 2016; Araujo et al. 2017; Gleason et al. 2017). Finally, wholeecosystem flux measurements using micrometeorological techniques can further confirm the dominant $\mathrm{Hg}^{0}$ deposition source to terrestrial ecosystems. The longest data set spans 2 years in the Arctic tundra (Obrist et al. 2017) and shows that $\mathrm{Hg}^{0}$ deposition $\left(6.5 \pm 0.7 \mu \mathrm{g} / \mathrm{m}^{2} /\right.$ year $)$ dominates other deposition processes (71\% of total deposition), in agreement with $\mathrm{Hg}$ stable isotope analysis. Previous studies over grasslands also reported a net annual dry $\mathrm{Hg}^{0}$ deposition [17.5 $\mu \mathrm{g} / \mathrm{m}^{2} /$ year (Fritsche et al. 2008a) and $3.3 \mu \mathrm{g} / \mathrm{m}^{2} /$ year (Castro and Moore 2016)] and shorter-term measurements showed a net $\mathrm{Hg}^{0}$ deposition during vegetation periods (Lee et al. 2000; Bash and Miller 2008; Fritsche et al. 2008b; Bash and Miller 2009; Sommar et al. 2016). Other studies, however, have reported inconsistent results, with net terrestrial $\mathrm{Hg}^{0}$ emissions even in the presence of vegetation (Lindberg et al. 1998; Cobos et al. 2002; Obrist et al. 2005; Cobbett and Van Heyst 2007; Baya and Van Heyst 2010).

\section{Atmosphere-aquatic interactions}

A new global model suggests that approximately $50 \%$ of total global wet $\mathrm{Hg}^{\mathrm{II}}$ deposition may occur to tropical oceans within $30^{\circ}$ northern and southern latitudes due to a high abundance of free tropospheric $\mathrm{Hg}^{\mathrm{II}}$ reservoirs scavenged by precipitation in these regions (Horowitz et al. 2017). These important global hotspot regions for $\mathrm{Hg}^{\mathrm{II}}$ deposition need to be confirmed by direct deposition measurements.

Air-sea exchange of $\mathrm{Hg}^{0}$ is critical to extending the lifetime of anthropogenic $\mathrm{Hg}$ in the atmosphere, terrestrial ecosystems, and the ocean (Strode et al. 2007; Soerensen et al. 2010). The magnitude of net $\mathrm{Hg}^{0}$ evasion from the ocean is approximately $2900 \mathrm{Mg} /$ year (range 1900-4200 Mg/year) (Horowitz et al. 2017; Streets et al. 2017), compared to approximately $2000 \mathrm{Mg} /$ year from primary anthropogenic emissions; thus, the ocean is considered the largest source of atmospheric $\mathrm{Hg}$ globally. There is, however, substantial uncertainty in the magnitude of air-sea exchange from different ocean regions. Simultaneous measurements of dissolved $\mathrm{Hg}^{0}$ in seawater and atmospheric concentrations are used to assess this source, with recent latitudinal gradients in both the Atlantic and Pacific Oceans showing distinct spikes in concentrations around the Intertropical Convergence Zone (ITCZ). These spikes are thought to result from deep convection and intense precipitation in these regions that increase atmospheric $\mathrm{Hg}^{\mathrm{II}}$ deposition (Soerensen et al. 2014). Using high-frequency measurements of atmospheric and aquatic $\mathrm{Hg}^{0}$ concentrations, Soerensen et al. (2013) inferred that terrestrial DOC can inhibit $\mathrm{Hg}^{\mathrm{II}}$ reduction and ambient $\mathrm{Hg}^{\mathrm{O}}$ production in seawater. Lamborg et al. (2016) measured concentrations of $\mathrm{Hg}$ on settling organic particulate matter in the Atlantic Ocean and suggested that partitioning to particles may be up to 1000 times greater than assumed in some models. This would effectively lower the magnitude of the global evasion flux of $\mathrm{Hg}^{0}$ from the ocean because scavenging of $\mathrm{Hg}$ from surface waters would reduce the pool of $\mathrm{Hg}^{\mathrm{II}}$ available for reduction and conversion to $\mathrm{Hg}^{0}$.

\section{Terrestrial-aquatic interactions}

In watersheds of the Americas, with historic $\mathrm{Hg}$ and precious metal mining, runoff from contaminated sites dominates aquatic $\mathrm{Hg}$ loads and is substantial $(44 \mathrm{Mg} /$ year) (Kocman et al. 2017). In contrast, in developed regions, including Europe and North America, catchment inputs and atmospheric deposition are generally the primary $\mathrm{Hg}$ sources, with background terrestrial environments accounting for approximately $230 \mathrm{Mg} /$ year $(170-300 \mathrm{Mg}$ ) of riverine loads. Hydrology and DOC mobility are the major controls on delivery of catchment $\mathrm{Hg}$ to aquatic ecosystems, with episodic high-flow periods from storms and/or snowmelt often representing the majority of annual catchment inputs (St. Louis et al. 2016).

Recent $\mathrm{Hg}$ stable isotope analyses have been able to differentiate among inorganic $\mathrm{Hg}$ sources to freshwater. The waters of remote Canadian lakes share the positive $\Delta^{200} \mathrm{Hg}$ signature observed in precipitation, suggesting that atmospheric deposition to these lakes is the major $\mathrm{Hg}$ source ( $42 \pm 26 \%$ ) (Chen et al. 2016). Similarly, analyses of sediment of the Laurentian Great Lakes indicate that atmospheric $\mathrm{Hg}^{\mathrm{II}}$ deposition is the dominant $\mathrm{Hg}$ source to Lakes Huron, Superior, and Michigan, while terrestrial catchment and industrial effluent are the dominant $\mathrm{Hg}$ sources to Lakes Erie and Ontario (Jackson et al. 2015; Lepak et al. 2015). Contrasting results have been reported for a boreal forest catchment in Sweden, where $\mathrm{Hg}$ stable isotope analyses suggest that $\mathrm{Hg}$ in forest runoff originated from the deposition of $\mathrm{Hg}^{0}$ through foliar uptake, rather than from precipitation (Jiskra et al. 2017). Analyses of dated lake sediment cores and catchment soils using geochemical tracers can also be used to tease apart changes in atmospheric and terrestrial $\mathrm{Hg}^{\mathrm{II}}$ inputs over time (Fitzgerald et al. 2005; Perry et al. 2005; Landers et al. 
2008; Muir et al. 2009; Kirk et al. 2011; Hermanns and Biester 2013). Recent analyses of $\mathrm{Hg}$ stable isotopes in dated lake sediment cores have also been used to examine temporal changes in $\mathrm{Hg}$ sources (Sonke et al. 2010; Gehrke et al. 2011; Cooke et al. 2013; Donovan et al. 2013).

For pelagic ocean regions, the dominant source of $\mathrm{Hg}$ is atmospheric deposition (Soerensen et al. 2010). Rivers comprise only a small fraction of $\mathrm{Hg}$ input to most ocean basins because the majority of $\mathrm{Hg}$ is in the particle phase and settles in ocean margins. Zhang et al. (2015b) showed that the fraction of riverine $\mathrm{Hg}$ exported to the open ocean is $6-25 \%$ for all basins except the Arctic. The large shelf and relatively smaller surface area of the Arctic Ocean make riverine inputs of $\mathrm{Hg}$ a more important source. For example, modeling studies have used atmospheric observations to infer a large missing $\mathrm{Hg}$ source from rivers and coastal erosion (Fisher et al. 2012; Zhang et al. 2015b). Other work using measured $\mathrm{Hg}$ :DOC ratios and a synthesis of available observations suggests a riverine $\mathrm{Hg}$ source to the Arctic of approximately $50 \mathrm{Mg} /$ year (Dastoor et al. 2015; Zhang et al. 2015b), which is slightly larger than atmospheric deposition of $\mathrm{Hg}$ (approximately $45 \mathrm{Mg} /$ year).

\section{ANTICIPATED IMPACTS FROM HUMAN AND NATURAL PERTURBATIONS, INCLUDING EMISSION CHANGES AND CLIMATE CHANGE, ON GLOBAL HG CYCLING}

As illustrated in Fig. 2, drivers of perturbations on the global $\mathrm{Hg}$ cycle include emission, climate, and land use changes.

\section{Atmosphere}

Critical factors affecting future anthropogenic emissions include energy use and $\mathrm{Hg}$ emission control strategies [e.g., in response to the Minamata Convention, see Selin et al. 2018 and Giang et al. 2015] and mitigation measures for global climate change. One of the largest anthropogenic sources of $\mathrm{Hg}$, ASGM emissions, will critically affect future $\mathrm{Hg}$ emissions, but is also associated with the largest uncertainties in future emission estimates. Streets et al. (2009) projected the range of 2050 global $\mathrm{Hg}$ emissions to be $2390-4860 \mathrm{Mg}$, compared to the 2006 level of $2480 \mathrm{Mg}$. For combustion sources, large-scale deployment of advanced $\mathrm{Hg}$ sorbent technologies, such as activated carbon injection (ACI), may lower the 2050 emission range to $1670-3480 \mathrm{Mg} /$ year. A study by Giang et al. (2015) suggested 90 and $150 \mathrm{Mg} /$ year of avoided power sector emissions for China and India in 2050, respectively, due to Minamata Convention control technology requirements. Declining $\mathrm{Hg}$ emissions in China through 2050 could, however, be offset by increasing Indian emissions (Giang et al. 2015), leading to a shift in source areas globally toward the tropics. Rafaj et al. (2013) evaluated the cobenefit of global greenhouse gas mitigation efforts and found that anthropogenic $\mathrm{Hg}$ emissions under a global climate mitigation regime would be reduced in 2050 by $45 \%$ compared to the case without climate measures. Pacyna et al. (2016) estimated that a best-case scenario of $\mathrm{Hg}$ emission decreases by 2050 could result in a decrease in $\mathrm{Hg}$ of up to $50 \%$ in the northern hemisphere and $35 \%$ in the southern hemisphere.

Lei et al. (2014) compared the influence of projected emission changes and climate change on U.S. atmospheric $\mathrm{Hg}$ levels in 2050. They found that anthropogenic emissions would contribute $32-53 \%$ of projected changes in $\mathrm{Hg}$ air concentration, while climate and natural emission changes would account for $47-68 \%$. Of the effects of climate change, influences via secondary emissions and ecosystem structure (see the "Atmosphere-terrestrial interactions" section) will likely exert the largest changes on atmospheric Hg pools. Although less important, atmospheric processes can also be directly impacted by climate change; for example, the oxidation rate constant of the $\mathrm{Hg}-$ $\mathrm{Br}$ reaction is sensitive to temperature. Zhang et al. (2016a) estimated a 5-7\% increase in northern hemisphere atmospheric surface $\mathrm{Hg}^{0}$ concentrations by 2050 because of reduced oxidation and increased in-cloud reduction. Changes in precipitation patterns can change spatial distribution, magnitude, and seasonal variation of $\mathrm{Hg}^{\mathrm{II}}$ deposition. Megaritis et al. (2014) projected increases in $\mathrm{Hg}^{\mathrm{II}}$ deposition due to climate change to the eastern U.S. of $6 \%$ during summer and $4 \%$ during winter by 2050 , with significant spatial variability. Zhang et al. (2016a) predicted that land use and land cover changes may lead to increases in $\mathrm{Hg}^{0}$ dry deposition fluxes under future climate. Hansen et al. (2015) projected climate-induced decreases in $\mathrm{Hg}$ deposition to the Arctic, while Zhang et al. (2016a) estimated increases in northern high latitudes. Large-scale meteorological patterns such as El Niño-Southern Oscillation may also influence interannual variability of atmospheric Hg concentrations (Slemr et al. 2016).

\section{Terrestrial}

Major impacts on global $\mathrm{Hg}$ cycling are expected due to shifts in global biomes, hydrology, fire patterns, water table depth, soil moisture, and redox conditions. In addition, forestry practices and deforestation can affect watershed $\mathrm{Hg}$ processes and $\mathrm{MeHg}$ exposures and biomagnification, although responses can be variable between different watersheds (discussed in detail in HsuKim et al. (2018)). Based on the importance of vegetation for atmospheric $\mathrm{Hg}$ deposition, predicted shifts in biomes 
will directly impact terrestrial and aquatic $\mathrm{Hg}$ distribution and impacts. Modeling studies have predicted a strong sensitivity of $\mathrm{Hg}^{0}$ dry deposition to changes in vegetation (Krabbenhoft and Sunderland 2013; Zhang et al. 2016a). Zhang et al. (2016a) projected that by 2050 the annual mean $\mathrm{Hg}^{0}$ dry deposition flux over land will increase by $20 \%$ in northern mid-latitudes, driven by a combination of increased atmospheric $\mathrm{Hg}^{0}$ exposure and increased vegetation and foliage density induced by $\mathrm{CO}_{2}$ fertilization. Regionally decreased $\mathrm{Hg}^{0}$ dry deposition may occur in South Asia and Africa, for example, where projected increases of agricultural land area will lead to losses of leafy areas. Strong shifts in soil $\mathrm{Hg}$ accumulation have been predicted as well. Hararuk et al. (2013) suggested that, along with changes in soil organic carbon, soil $\mathrm{Hg}$ sequestration in the U.S. will increase by 2100 , mainly induced by changes in precipitation patterns. They also predicted that increases in $\mathrm{CO}_{2}$ concentrations to $700 \mathrm{ppm}$ would stimulate both soil carbon and soil $\mathrm{Hg}$ accruals, while increased air temperatures would have small negative effects on both. The combined effects of increased $\mathrm{CO}_{2}$, increased temperature, and increased or decreased precipitation will likely lead to pronounced regional differences in soil Hg changes. Anticipated shifts in coniferous versus deciduous forest abundance will also likely impact terrestrial $\mathrm{Hg}$ distribution. Richardson and Friedland (2015) suggested that anticipated losses of 2.2 million ha of coniferous forests will lead to $27 \mathrm{Mg}$ less $\mathrm{Hg}$ sequestered in organic horizons across this region, either as a function of reduced atmospheric $\mathrm{Hg}$ deposition or increased release into watersheds. These anticipated effects of climate change and ecosystem properties on $\mathrm{Hg}$ cycling can be seen clearly in archive studies. In a remote lake in Patagonia, for example, pre-anthropogenic changes in sediment loads up to a factor of four were found, comparable to recent anthropogenic forcing (Hermanns et al. 2012), and were attributed to past changes in deposition related to climate-induced shifts in terrestrial organic matter flux and DOM leaching from catchment soils. Similarly, Rydberg et al. (2015) documented how a climate-induced change from deciduous to coniferous forests around 5700 years BP led to reduced soil erosion and increased transport of DOC-bound $\mathrm{Hg}$ from a catchment in the area of Germany, resulting in increased $\mathrm{Hg}$ concentrations and accumulation rates.

Other ecosystem disturbances are expected to affect $\mathrm{Hg}$ cycling, but in unknown directions. For example, changes in wildfire frequency and abundance will impact atmospheric $\mathrm{Hg}$ emissions and watershed fluxes in a nonlinear fashion given the complex relationships between $\mathrm{Hg}$ emissions and fire intensities, pre-fire $\mathrm{Hg}$ accumulation, and post-fire $\mathrm{Hg}$ mobilization. Wildfire $\mathrm{Hg}$ emissions now likely include substantial emissions of anthropogenic legacy $\mathrm{Hg}$ accumulated in litter and soils, and climate and land use change impacts on fire frequency and activity need to be considered as part of human impacts (Westerling et al. 2006). A recent modeling study (Kumar et al. 2017) estimated a $14 \%$ increase in wildfire-related $\mathrm{Hg}$ emission due to climate change. Corresponding land use changes may amplify or alleviate this effect, e.g., due to reductions in forest fires by agricultural land expansion in Africa or increased forest abundance in North America and Asia. In addition, land management practices such as burning of agricultural fields, grassland, and brush fires contribute to $\mathrm{Hg}$ emissions, although little information is available on their global contribution. Land use changes such as shifts in land management and forestry practices also have the potential to mobilize terrestrial $\mathrm{Hg}$ pools, via increased erosion, changes in hydrological pathways, and changes in yields (Kocman et al. 2017; Kronberg et al. 2016). Kocman et al. (2017) summarized studies that show pronounced $\mathrm{Hg}$ leaching when soils are converted to agricultural land and predicted that global deforestation of 13 million ha/yr in the 2000s may have yielded up to $260 \mathrm{Mg} \mathrm{Hg}$ per year entering local freshwaters.

\section{Aquatic systems}

Both oceans and freshwater ecosystems will be affected by changing $\mathrm{Hg}$ emissions and climate-induced alterations. Modeling studies show that response times for lakes can range from a few years to many decades (Harris et al. 2007; Knightes et al. 2009). Recovery of freshwater ecosystems to decreased atmospheric $\mathrm{Hg}$ emissions is expected when reduced atmospheric $\mathrm{Hg}$ loadings translates into a substantial decrease in DOC-bound $\mathrm{MeHg}$ and inorganic $\mathrm{Hg}$ catchment runoff (Graham et al. 2013; Chiasson-Gould et al. 2014; French et al. 2014; Jonsson et al. 2014; Lepak et al. 2015; Ndu et al. 2015). A recent long-term mass balance study in New York state suggested that Hg inputs to lakes from forested catchments could be very responsive to decreased $\mathrm{Hg}$ emissions (Gerson and Driscoll 2016). They reported that a $25 \%$ reduction in atmospheric $\mathrm{Hg}^{0}$ concentration resulted in a $40 \%$ reduction in litterfall $\mathrm{Hg}$ fluxes, which in turn decreased inorganic $\mathrm{Hg}$ and $\mathrm{MeHg}$ stream inputs (45 and 29\%, respectively) and lake concentrations over a 10-year period (Gerson and Driscoll 2016).

A common disturbance of freshwater $\mathrm{Hg}$ cycling results from widespread reservoir creation, which generally amplifies $\mathrm{MeHg}$ production; reservoir effects are discussed in detail in Eagles-Smith et al. (2018) and Hsu-Kim et al. (2018). Most studies of climate change impacts on freshwater $\mathrm{Hg}$ cycling have been conducted in sensitive ecosystems experiencing accelerated changes (e.g., highaltitude and high-latitude lakes, ponds, and peatlands). In 
the western Canadian Arctic, where approximately $15 \%$ of the water bodies have shoreline retrogressive thaw slump lakes, lake sediment cores demonstrated increased sedimentation of inorganics and decreased sediment concentrations of DOC, $\mathrm{THg}$, and $\mathrm{MeHg}$ (Deison et al. 2012). In contrast, a survey of $\mathrm{MeHg}$ accumulation in invertebrates in tundra lakes suggested that lakes with low DOC are experiencing increased DOC input because of humification and these lakes may see a two- to threefold increase in $\mathrm{Hg}$ bioaccumulation as the DOC concentration approaches a threshold of approximately $8 \mathrm{mg} / \mathrm{L}$ (MacMillan et al. 2015). Jonsson et al. (2017) predicted a three- to sixfold increase in $\mathrm{MeHg}$ concentration in estuarine zooplankton in association with large inputs of terrestrial DOC intended to mimic potential future changes in runoff. Peat mesocosm experiments suggest that changes in hydrological regimes and shifts in vascular plant communities may have a significant impact on Hg cycling in peatlands (Haynes 2017). For example, lower, more variable water tables and the removal of Ericaceae shrubs significantly enhanced inorganic $\mathrm{Hg}$ and $\mathrm{MeHg}$ mobility in peat pore waters and $\mathrm{MeHg}$ export from snowmelt, likely from enhanced peat decomposition and internal regeneration of electron acceptors related to water table changes (Haynes et al. 2017).

The effect on $\mathrm{Hg}$ of large-scale changes in the marine environment expected from climate change was explored by Krabbenhoft and Sunderland (2013). Increased seawater temperatures may enhance organic matter remineralization and the propensity for $\mathrm{MeHg}$ production in some regions of the ocean. Rapid changes in sea-ice cover and seasonality in the polar oceans are likely to exert a major impact on air-sea exchange of $\mathrm{Hg}$ in these regions, and further work may be needed to understand how temperature and sea-ice dynamics alter $\mathrm{Hg}$ dynamics in the Arctic (Angot et al. 2016). Changes in microbial community structure and ocean productivity will propagate through marine food webs in potentially unexpected ways, altering bioaccumulation. Fisher et al. (2013) used 30 years of satellite data to quantify the impacts of interannual variability in meteorology on inorganic $\mathrm{Hg}$ dynamics in the Arctic. They concluded that the dominant climate mode of the future in the Arctic may result in a lower reservoir of $\mathrm{Hg}$ in the Arctic Ocean because of enhanced air-sea exchange. This work did not consider the effects of a changing (melting) terrestrial landscape, which may dramatically increase $\mathrm{Hg}$ input to the Arctic from the terrestrial environment. Soerensen et al. (2016) suggested that rivers are likely to become more dominant sources of $\mathrm{Hg}$ and $\mathrm{MeHg}$ in the future Arctic Ocean. Stern et al. (2012) reviewed a variety of changes that are occurring and expected to occur in the Arctic Ocean in the future, and suggested that future effects are likely to be large; they also highlighted current limitations in understanding multiple, simultaneously occurring impacts on $\mathrm{Hg}$ cycling and bioaccumulation. Finally, recent modeling suggests that the response times of marine fish tissue burdens to changes in $\mathrm{Hg}$ input will depend on the locations of $\mathrm{MeHg}$ production ( $\mathrm{Li}$ et al. 2016). Benthic sediment will respond much more slowly than the upper Ocean and estuarine surface waters (Sunderland et al. 2010; Schartup et al. 2015; Soerensen et al. 2016). Amos et al. (2013) predicted that legacy $\mathrm{Hg}$ will be present in global ecosystems for periods ranging from decades to millennia, suggesting a large time lag in response to changes in anthropogenic emissions and climate.

\section{CONCLUSIONS AND REMAINING UNCERTAINTIES}

We reviewed how our understanding of $\mathrm{Hg}$ global cycling has advanced in the last decade, focusing on environmental reservoirs and processes within and between these reservoirs. With emerging large global datasets, in combination with improved models and analytical techniques, new constraints are possible on the magnitude of reservoirs and fluxes. In the atmosphere, while $\mathrm{Hg}^{0}$ concentrations and wet deposition are decreasing in some parts of Europe and North America, other regions such as Asia show increasing trends. Updated knowledge about the presence and chemistry of $\mathrm{Hg}^{\mathrm{II}}$, especially in the free troposphere, suggests a source of global $\mathrm{Hg}$ to the tropics. In terrestrial ecosystems, updated information gained from new measurements and models has changed our understanding of $\mathrm{Hg}$ exchange between terrestrial systems and the ocean. Previous estimates of a large terrestrial source of $\mathrm{Hg}$ to the atmosphere have been revised downward, and new data suggest that $\mathrm{Hg}^{0}$ uptake is dominant in natural systems. In aquatic systems, recent research has shown the potential importance of direct $\mathrm{Hg}$ releases to water in both freshwater and marine systems. In oceans, new constraints are available on the total amount of $\mathrm{Hg}$ in ocean systems and its distribution and trends, with declines in the Atlantic and possible increases in the Pacific.

Global changes, including climate, land use, and $\mathrm{Hg}$ emissions changes, are likely to profoundly alter $\mathrm{Hg}$ cycling. New analyses have indicated the direction of these possible changes. Global policy such as that emerging from the Minamata Convention may avoid significant increases in $\mathrm{Hg}$ concentrations associated with future economic growth; however, legacy emissions will continue to affect the global cycle for decades to centuries. Projections of future conditions are becoming more quantitative, supported by increasingly large and globally linked datasets, new tools, and better models. Global changes are also 
expected to affect concentrations of $\mathrm{MeHg}$ in potentially nonlinear ways, including changes in methylation and food web bioaccumulation [see Eagles-Smith et al. (2018) and Hsu-Kim et al. (2018)].

There remain uncertainties that limit our ability to predict future global cycling and therefore human exposure, especially in the context of multiple and simultaneous changes. While data availability has increased, several regions of the globe, especially the tropics and the southern hemisphere, remain understudied. In the atmosphere, uncertainties in atmospheric chemistry and in measurements of $\mathrm{Hg}^{\mathrm{II}}$ challenge our quantitative understanding of oxidation pathways. Advances and wider applications in isotope techniques are needed to better fingerprint specific sources and mechanisms. In terrestrial ecosystems, timeextended measurements of $\mathrm{Hg}^{0}$ uptake, now known to be a significant input process, are largely lacking. Finally, the global $\mathrm{Hg}$ cycle will also depend on the choices made by governments both now and in the future, including policy efforts to mitigate emissions of $\mathrm{Hg}$ and control climate change.

Acknowledgements This paper was written as part of the synthesis effort for the 13th International Conference on Mercury as a Global Pollutant, Providence, Rhode Island, July 16-21, 2017. We thank Dan Jaffe, Jeroen E. Sonke, Xinbin Feng, Robert Mason, David Krabbenhoft, Alexandra Steffen, and Jason Stowe for valuable inputs, technical reviews, and comments on earlier drafts of this paper. Grant support was provided by the Dartmouth College Toxic Metals Superfund Research Program through funds from the National Institute of Environmental Health Sciences of the National Institutes of Health under Award Numbers R13 ES028077-01 and P42ES007373. Support was also provided by US National Science Foundation (NSF) award PLR \#1304305) and NSF CNH \#1313755 and by a H2020 Marie Sklodowska-Curie Grant Agreement \#657195. The content of this paper is solely the responsibility of the authors and does not necessarily represent the official views of the funding agencies.

Open Access This article is distributed under the terms of the Creative Commons Attribution 4.0 International License (http:// creativecommons.org/licenses/by/4.0/), which permits unrestricted use, distribution, and reproduction in any medium, provided you give appropriate credit to the original author(s) and the source, provide a link to the Creative Commons license, and indicate if changes were made.

\section{REFERENCES}

Agnan, Y., T. Le Dantec, C.W. Moore, G.C. Edwards, and D. Obrist. 2016. New constraints on terrestrial surface-atmosphere fluxes of gaseous elemental mercury using a global database. Environmental Science and Technology 50: 507-524.

AMAP/UNEP. 2008. Technical Background Report to the Global Atmospheric Mercury Assessment. Arctic Monitoring and Assessment Programme and United Nations Environment Programme, Geneva, Switzerland
AMAP/UNEP. 2013. Technical Background Report for the Global Mercury Assessment 2013. Arctic Monitoring and Assessment Programme and United Nations Environment Programme, Geneva, Switzerland

Amos, H.M., D.J. Jacob, D.G. Streets, and E.M. Sunderland. 2013 Legacy impacts of all-time anthropogenic emissions on the global mercury cycle. Global Biogeochemical Cycles 27: 410-421.

Amos, H.M., D.J. Jacob, D. Kocman, H.M. Horowitz, Y. Zhang, S. Dutkiewicz, M. Horvat, E.S. Corbitt, et al. 2014. Global biogeochemical implications of mercury discharges from rivers and sediment burial. Environmental Science and Technology 48: 9514-9522.

Amos, H.M., J.E. Sonke, D. Obrist, N. Robins, N. Hagan, H.M. Horowitz, R.P. Mason, M. Witt, et al. 2015. Observational and modeling constraints on global anthropogenic enrichment of mercury. Environmental Science and Technology 49: 4036-4047.

Angot, H., A. Dastoor, F. De Simone, K. Gårdfeldt, C.N. Gencarelli, I.M. Hedgecock, S. Langer, O. Magand, et al. 2016. Chemical cycling and deposition of atmospheric mercury in polar regions: Review of recent measurements and comparison with models. Atmospheric Chemistry and Physics. https://doi.org/10.5194/ acp-16-10735-2016.

Araujo, B.F., H. Hintelmann, B. Dimock, M.G. Almeida, and C.E. Rezende. 2017. Concentrations and isotope ratios of mercury in sediments from shelf and continental slope at Campos Basin near Rio de Janeiro, Brazil. Chemosphere 178: 42-50.

Bae, H.S., F.E. Dierberg, and A. Ogram. 2014. Syntrophs dominate sequences associated with the mercury methylation-related gene hgcA in the water conservation areas of the Florida Everglades. Applied and Environment Microbiology 80: 6517-6526.

Bash, J.O., and D.R. Miller. 2008. A relaxed eddy accumulation system for measuring surface fluxes of total gaseous mercury. Journal of Atmospheric and Oceanic Technology 25: 244-257.

Bash, J.O., and D.R. Miller. 2009. Growing season total gaseous mercury (TGM) flux measurements over an Acer rubrum L. stand. Atmospheric Environment 43: 5953-5961.

Bash, J.O., P. Bresnahan, and D.R. Miller. 2007. Dynamic surface interface exchanges of mercury: A review and compartmentalized modeling framework. Journal of Applied Meteorology and Climatology 46: 1606-1618.

Baya, A.P., and B. Van Heyst. 2010. Assessing the trends and effects of environmental parameters on the behaviour of mercury in the lower atmosphere over cropped land over four seasons. Atmospheric Chemistry and Physics 10: 8617-8628.

Benoit, J.M., C.C. Gilmour, R.P. Mason, and A. Heyes. 1999. Sulfide controls on mercury speciation and bioavailability to methylating bacteria in sediment pore waters. Environmental Science and Technology 33: 951-957.

Bergquist, B.A., and J.D. Blum. 2007. Mass-dependent and independent fractionation of $\mathrm{Hg}$ isotopes by photoreduction in aquatic systems. Science 318: 417-420.

Bieser, J., F. Slemr, J. Ambrose, C. Brenninkmeijer, S. Brooks, A. Dastoor, F. DeSimone, R. Ebinghaus, et al. 2017. Multi-model study of mercury dispersion in the atmosphere: Vertical and interhemispheric distribution of mercury species. Atmospheric Chemistry and Physics 17: 6925-6955.

Biester, H., R. Bindler, A. Martinez-Cortizas, and D.R. Engstrom. 2007. Modeling the past atmospheric deposition of mercury using natural archives. Environmental Science and Technology 41: 4851-4860.

Bigeleisen, J. 1996. Nuclear size and shape effects in chemical reactions. Isotope chemistry of the heavy elements. Journal of the American Chemical Society 118: 3676-3680. 
Biswas, A., J.D. Blum, B. Klaue, and G.J. Keeler. 2007. Release of mercury from Rocky Mountain forest fires. Global Biogeochemical Cycles. https://doi.org/10.1029/2006GB002696.

Biswas, A., J.D. Blum, and G.J. Keeler. 2008. Mercury storage in surface soils in a central Washington forest and estimated release during the 2001 Rex Creek Fire. Science of the Total Environment 404: 129-138.

Blackwell, B.D., and C.T. Driscoll. 2015. Deposition of mercury in forests along a montane elevation gradient. Environmental Science and Technology 49: 5363-5370.

Blais, J.M., M. Rosen, and J.P. Smol. 2015. Environmental contaminants: Using natural archives to track sources and long-term trends of pollution. Berlin: Springer.

Blum, J.D., and B.A. Bergquist. 2007. Reporting of variations in the natural isotopic composition of mercury. Analytical and Bioanalytical Chemistry 388: 353-359.

Blum, J.D., and M.W. Johnson. 2017. Recent developments in mercury stable isotope analysis. Reviews in Mineralogy and Geochemistry 82: 733.

Blum, J.D., B.N. Popp, J.C. Drazen, C. Anela Choy, and M.W. Johnson. 2013. Methylmercury production below the mixed layer in the North Pacific Ocean. Nature Geoscience 6: 879-884.

Blum, J.D., L.S. Sherman, and M.W. Johnson. 2014. Mercury isotopes in earth and environmental sciences. Annual Review of Earth and Planetary Sciences 42: 249-269.

Boening, D.W. 2000. Ecological effects, transport, and fate of mercury: A general review. Chemosphere 40: 1335-1351.

Bowman, K.L., C.R. Hammerschmidt, C.H. Lamborg, and G. Swarr. 2014. Mercury in the North Atlantic Ocean: The US GEOTRACES zonal and meridional sections. Deep Sea Research Part II: Topical Studies in Oceanography 116: 251-261.

Bowman, K.L., C.R. Hammerschmidt, C.H. Lamborg, G.J. Swarr, and A.M. Agather. 2016. Distribution of mercury species across a zonal section of the eastern tropical South Pacific Ocean (U.S. GEOTRACES GP16). Marine Chemistry 186: 156-166.

Bravo, A.G., S. Bouchet, S. Guedron, D. Amouroux, J. Dominik, and J. Zopfi. 2015. High methylmercury production under ferruginous conditions in sediments impacted by sewage treatment plant discharges. Water Research 80: 245-255.

Buchachenko, A.L. 2001. Magnetic isotope effect: Nuclear spin control of chemical reactions. The Journal of Physical Chemistry A 105: 9995-10011.

Buchachenko, A.L. 2009. Mercury isotope effects in the environmental chemistry and biochemistry of mercury-containing compounds. Russian Chemical reviews 78: 319-328.

Burger Chakraborty, L., A. Qureshi, C. Vadenbo, and S. Hellweg. 2013. Anthropogenic mercury flows in India and impacts of emission controls. Environmental Science and Technology 47: $8105-8113$.

Burke, M.P., T.S. Hogue, M. Ferreira, C.B. Mendez, B. Navarro, S. Lopez, and J.A. Jay. 2010. The effect of wildfire on soil mercury concentrations in Southern California watersheds. Water, Air, and Soil Pollution 212: 369-385.

Butler, T.J., M.D. Cohen, F.M. Vermeylen, G.E. Likens, D. Schmeltz, and R.S. Artz. 2008. Regional precipitation mercury trends in the eastern USA, 1998-2005: Declines in the Northeast and Midwest, no trend in the Southeast. Atmospheric Environment 42: $1582-1592$.

Castro, M., and C. Moore. 2016. Importance of gaseous elemental mercury fluxes in western Maryland. Atmosphere 7: 110.

Chen, J., H. Hintelmann, X. Feng, and B. Dimock. 2012. Unusual fractionation of both odd and even mercury isotopes in precipitation from Peterborough, ON, Canada. Geochimica et Cosmochimica Acta 90: 33-46.

Chen, J., H. Hintelmann, W. Zheng, X. Feng, H. Cai, Z. Wang, S. Yuan, and Z. Wang. 2016. Isotopic evidence for distinct sources of mercury in lake waters and sediments. Chemical Geology 426: $33-44$.

Chiasson-Gould, S.A., J.M. Blais, and A.J. Poulain. 2014. Dissolved organic matter kinetically controls mercury bioavailability to bacteria. Environmental Science and Technology 48: 3153-3161.

Choi, H.D., and T.M. Holsen. 2009. Gaseous mercury fluxes from the forest floor of the Adirondacks. Environmental Pollution 157: 592-600.

Christensen, G.A., A.M. Wymore, A.J. King, M. Podar, R.A. Hurt Jr., E.U. Santillan, A. Soren, C.C. Brandt, et al. 2016. Development and validation of broad-range qualitative and clade-specific quantitative molecular probes for assessing mercury methylation in the environment. Applied and Environment Microbiology 82: 6068-6078.

Cobbett, F.D., and B.J. Van Heyst. 2007. Measurements of GEM fluxes and atmospheric mercury concentrations (GEM, RGM and $\mathrm{Hg}-\mathrm{P}$ ) from an agricultural field amended with biosolids in Southern Ont., Canada (October 2004-November 2004). Atmospheric Environment 41: 2270-2282.

Cobos, D., J. Baker, and E. Nater. 2002. Conditional sampling for measuring mercury vapor fluxes. Atmospheric Environment 36: $4309-4321$.

Cole, A.S., A. Steffen, K.A. Pfaffhuber, T. Berg, M. Pilote, L. Poissant, R. Tordon, and H. Hung. 2013. Ten-year trends of atmospheric mercury in the high Arctic compared to Canadian sub-Arctic and mid-latitude sites. Atmospheric Chemistry and Physics 13: 1535-1545.

Cole, A., A. Steffen, C. Eckley, J. Narayan, M. Pilote, R. Tordon, J. Graydon, V.L. St Louis, et al. 2014. A survey of mercury in air and precipitation across Canada: Patterns and trends. Atmosphere 5: 635-668.

Cooke, C.A., H. Hintelmann, J.J. Ague, R. Burger, H. Biester, J.P. Sachs, and D.R. Engstrom. 2013. Use and legacy of mercury in the Andes. Environmental Science and Technology 47: 4181-4188.

Cossa, D., J.-M. Martin, K. Takayanagi, and J. Sanjuan. 1997. The distribution and cycling of mercury species in the western Mediterranean. Deep Sea Research Part II: Topical Studies in Oceanography 44: 721-740.

Cossa, D., B. Averty, and N. Pirrone. 2009. The origin of methylmercury in open Mediterranean waters. Limnology and Oceanography 54: 837-844.

Cossa, D., L.-E. Heimbürger, D. Lannuzel, S.R. Rintoul, E.C.V. Butler, A.R. Bowie, B. Averty, R.J. Watson, et al. 2011. Mercury in the Southern Ocean. Geochimica et Cosmochimica Acta 75: 4037-4052.

Dastoor, A.P., and Y. Larocque. 2004. Global circulation of atmospheric mercury: A modelling study. Atmospheric Environment 38: 147-161.

Dastoor, A., A. Ryzhkov, D. Durnford, I. Lehnherr, A. Steffen, and H. Morrison. 2015. Atmospheric mercury in the Canadian Arctic. Part II: Insight from modeling. Science of the Total Environment 509-510: 16-27.

De Simone, F., S. Cinnirella, C.N. Gencarelli, X. Yang, I.M. Hedgecock, and N. Pirrone. 2015. Model study of global mercury deposition from biomass burning. Environmental Science and Technology 49: 6712-6721.

Deison, R., J.P. Smol, S.V. Kokelj, M.F. Pisaric, L.E. Kimpe, A.J. Poulain, H. Sanei, J.R. Thienpont, et al. 2012. Spatial and temporal assessment of mercury and organic matter in thermokarst affected lakes of the Mackenzie Delta uplands, NT, Canada. Environmental Science and Technology 46: 8748-8755.

Demers, J.D., J.D. Blum, and D.R. Zak. 2013. Mercury isotopes in a forested ecosystem: Implications for air-surface exchange dynamics and the global mercury cycle. Global Biogeochemical Cycles 27: 222-238. 
Demers, J.D., L.S. Sherman, J.D. Blum, F.J. Marsik, and J.T. Dvonch. 2015. Coupling atmospheric mercury isotope ratios and meteorology to identify sources of mercury impacting a coastal urban-industrial region near Pensacola, Florida, USA. Global Biogeochemical Cycles 29: 1689-1705.

Denzler, B., C. Bogdal, S. Henne, D. Obrist, M. Steinbacher, and K. Hungerbuhler. 2017. Inversion approach to validate mercury emissions based on background air monitoring at the high altitude research station Jungfraujoch $(3580 \mathrm{~m})$. Environmental Science and Technology 51: 2846-2853.

Dibble, T.S., M.J. Zelie, and H. Mao. 2012. Thermodynamics of reactions of $\mathrm{ClHg}$ and $\mathrm{BrHg}$ radicals with atmospherically abundant free radicals. Atmospheric Chemistry and Physics 12: 10271-10279.

Donovan, P.M., J.D. Blum, D. Yee, G.E. Gehrke, and M.B. Singer. 2013. An isotopic record of mercury in San Francisco Bay sediment. Chemical Geology 349-350: 87-98.

Drevnick, P.E., C.A. Cooke, D. Barraza, J.M. Blais, K.H. Coale, B.F. Cumming, C.J. Curtis, B. Das, et al. 2016. Spatiotemporal patterns of mercury accumulation in lake sediments of western North America. Science of the Total Environment 568: 1157-1170.

Driscoll, C.T., Y.J. Han, C.Y. Chen, D.C. Evers, K.F. Lambert, T.M. Holsen, N.C. Kamman, and R.K. Munson. 2007. Mercury contamination in forest and freshwater ecosystems in the Northeastern United States. BioScience 57: 17-28.

Du, H., M. Ma, T. Sun, X. Dai, C. Yang, F. Luo, D. Wang, and Y. Igarashi. 2017. Mercury-methylating genes dsrB and hgcA in soils/sediments of the Three Gorges Reservoir. Environmental Science and Pollution Research International 24: 5001-5011.

Durnford, D., A. Dastoor, A. Ryzhkov, L. Poissant, M. Pilote, and D. Figueras-Nieto. 2012. How relevant is the deposition of mercury onto snowpacks? Part 2: A modeling study. Atmospheric Chemistry and Physics 12: 9251-9274.

Eagles-Smith, C.A., E.K. Silbergeld, N. Basu, P. Bustamante, F. Diaz-Barriga, W.A. Hopkins, K.A. Kidd, and J.F. Nyland. 2018. Modulators of mercury risk to wildlife and humans in the context of rapid global change. Ambio. https://doi.org/10.1007/s13280017-1011-x.

Ebinghaus, R., S.G. Jennings, H.H. Kock, R.G. Derwent, A.J. Manning, and T.G. Spain. 2011. Decreasing trends in total gaseous mercury observations in baseline air at Mace Head, Ireland from 1996 to 2009. Atmospheric Environment 45: 3475-3480.

Eckley, C.S., M.T. Tate, C.J. Lin, M. Gustin, S. Dent, C. EaglesSmith, M.A. Lutz, K.P. Wickland, et al. 2016. Surface-air mercury fluxes across Western North America: A synthesis of spatial trends and controlling variables. Science of the Total Environment 568: 651-665.

Engle, M.A., M. Sexauer Gustin, D.W. Johnson, J.F. Murphy, W.W. Miller, R.F. Walker, J. Wright, and M. Markee. 2006. Mercury distribution in two Sierran forest and one desert sagebrush steppe ecosystems and the effects of fire. Science of the Total Environment 367: 222-233.

Engstrom, D.R., and E.B. Swain. 1997. Recent declines in atmospheric mercury deposition in the upper midwest. Environmental Science and Technology 31: 960-967.

Engstrom, D.R., W.F. Fitzgerald, C.A. Cooke, C.H. Lamborg, P.E. Drevnick, E.B. Swain, S.J. Balogh, and P.H. Balcom. 2014. Atmospheric $\mathrm{Hg}$ emissions from preindustrial gold and silver extraction in the Americas: A reevaluation from lake-sediment archives. Environmental Science and Technology 48: 6533-6543.

Enrico, M., G.L. Roux, N. Marusczak, L.E. Heimburger, A. Claustres, X. Fu, R. Sun, and J.E. Sonke. 2016. Atmospheric mercury transfer to peat bogs dominated by gaseous elemental mercury dry deposition. Environmental Science and Technology 50: 2405-2412.

Enrico, M., G. Le Roux, L.E. Heimburger, P. Van Beek, M. Souhaut, J. Chmeleff, and J.E. Sonke. 2017. Holocene atmospheric mercury levels reconstructed from peat bog mercury stable isotopes. Environmental Science and Technology 51: 5899-5906.

Ericksen, J.A., M.S. Gustin, M. Xin, P.J. Weisberg, and G.C. Fernandez. 2006. Air-soil exchange of mercury from background soils in the United States. Science of the Total Environment 366: $851-863$.

Faïn, X., C.P. Ferrari, A. Dommergue, M.R. Albert, M. Battle, J. Severinghaus, L. Arnaud, J.M. Barnola, et al. 2009. Polar firn air reveals large-scale impact of anthropogenic mercury emissions during the 1970s. Proceedings of the National academy of Sciences of the United States of America 106: 16114-16119.

Farmer, J.G., P. Anderson, J.M. Cloy, M.C. Graham, A.B. MacKenzie, and G.T. Cook. 2009. Historical accumulation rates of mercury in four Scottish ombrotrophic peat bogs over the past 2000 years. Science of the Total Environment 407: 5578-5588.

Fisher, J.A., D.J. Jacob, A.L. Soerensen, H.M. Amos, A. Steffen, and E.M. Sunderland. 2012. Riverine source of Arctic Ocean mercury inferred from atmospheric observations. Nature Geoscience 5: 499-504.

Fisher, J.A., D.J. Jacob, A.L. Soerensen, H.M. Amos, E.S. Corbitt, D.G. Streets, Q. Wang, R.M. Yantosca, et al. 2013. Factors driving mercury variability in the Arctic atmosphere and ocean over the past 30 years. Global Biogeochemical Cycles 27: $1226-1235$

Fitzgerald, W.F., D.R. Engstrom, C.H. Lamborg, C.M. Tseng, P.H. Balcom, and C.R. Hammerschmidt. 2005. Modern and historic atmospheric mercury fluxes in northern Alaska: Global sources and Arctic depletion. Environmental Science and Technology 39: $557-568$.

Fitzgerald, W.F., C.H. Lamborg, and C.R. Hammerschmidt. 2007. Marine biogeochemical cycling of mercury. Chemical Reviews 107: 641-662.

Fleck, J.A., M. Marvin-DiPasquale, C.A. Eagles-Smith, J.T. Ackerman, M.A. Lutz, M. Tate, C.N. Alpers, B.D. Hall, et al. 2016. Mercury and methylmercury in aquatic sediment across western North America. Science of the Total Environment 568: 727-738.

French, T.D., A.J. Houben, J.P. Desforges, L.E. Kimpe, S.V. Kokelj, A.J. Poulain, J.P. Smol, X. Wang, et al. 2014. Dissolved organic carbon thresholds affect mercury bioaccumulation in Arctic lakes. Environmental Science and Technology 48: 3162-3168.

Friedli, H.R., L.F. Radke, and J.Y. Lu. 2001. Mercury in smoke from biomass fires. Geophysical Research Letters 28: 3223-3226.

Friedli, H.R., L.F. Radke, J.Y. Lu, C.M. Banic, W.R. Leaitch, and J.I. MacPherson. 2003. Mercury emissions from burning of biomass from temperate North American forests: Laboratory and airborne measurements. Atmospheric Environment 37: 253-267.

Fritsche, J., D. Obrist, M. Zeeman, F. Conen, W. Eugster, and C. Alewell. 2008a. Elemental mercury fluxes over a sub-alpine grassland determined with two micrometeorological methods. Atmospheric Environment 42: 2922-2933.

Fritsche, J., G. Wohlfahrt, C. Ammann, M. Zeeman, A. Hammerle, D. Obrist, and C. Alewell. 2008b. Summertime elemental mercury exchange of temperate grasslands on an ecosystem-scale. Atmospheric Chemistry and Physics 8: 7709-7722.

Fu, X., X. Yang, X. Lang, J. Zhou, H. Zhang, B. Yu, H. Yan, C.-J. Lin, et al. 2016a. Atmospheric wet and litterfall mercury deposition at urban and rural sites in China. Atmospheric Chemistry and Physics 16: 11547-11562.

Fu, X., W. Zhu, H. Zhang, J. Sommar, B. Yu, X. Yang, X. Wang, C.J. Lin, et al. 2016b. Depletion of atmospheric gaseous elemental mercury by plant uptake at Mt. Changbai, Northeast China. Atmospheric Chemistry and Physics 16: 12861-12873. 
Gehrke, G.E., J.D. Blum, and M. Marvin-DiPasquale. 2011. Sources of mercury to San Francisco Bay surface sediment as revealed by mercury stable isotopes. Geochimica et Cosmochimica Acta 75: 691-705.

Gerson, J.R., and C.T. Driscoll. 2016. Is mercury in a remote forested watershed of the Adirondack mountains responding to recent decreases in emissions? Environmental Science and Technology 50: 10943-10950.

Giang, A., L.C. Stokes, D.G. Streets, E.S. Corbitt, and N.E. Selin. 2015. Impacts of the Minamata convention on mercury emissions and global deposition from coal-fired power generation in Asia. Environmental Science and Technology 49: 5326-5335.

Gilmour, C.C., M. Podar, A.L. Bullock, A.M. Graham, S.D. Brown, A.C. Somenahally, A. Johs, R.A. Hurt Jr., et al. 2013. Mercury methylation by novel microorganisms from new environments. Environmental Science and Technology 47: 11810-11820.

Gionfriddo, C.M., M.T. Tate, R.R. Wick, M.B. Schultz, A. Zemla, M.P. Thelen, R. Schofield, D.P. Krabbenhoft, et al. 2016. Microbial mercury methylation in Antarctic sea ice. Nature Microbiology 1: 16127.

Gleason, J.D., J.D. Blum, T.C. Moore, L. Polyak, M. Jakobsson, P.A. Meyers, and A. Biswas. 2017. Sources and cycling of mercury in the paleo Arctic Ocean from $\mathrm{Hg}$ stable isotope variations in Eocene and Quaternary sediments. Geochimica et Cosmochimica Acta 197: 245-262.

Goodsite, M.E., J.M. Plane, and H. Skov. 2004. A theoretical study of the oxidation of $\mathrm{Hg} 0$ to $\mathrm{HgBr} 2$ in the troposphere. Environmental Science and Technology 38: 1772-1776.

Goodsite, M.E., P.M. Outridge, J.H. Christensen, A. Dastoor, D. Muir, O. Travnikov, and S. Wilson. 2013. How well do environmental archives of atmospheric mercury deposition in the Arctic reproduce rates and trends depicted by atmospheric models and measurements? Science of the Total Environment 452-453: 196-207.

Graham, A.M., G.R. Aiken, and C.C. Gilmour. 2013. Effect of dissolved organic matter source and character on microbial $\mathrm{Hg}$ methylation in $\mathrm{Hg}-\mathrm{S}-\mathrm{DOM}$ solutions. Environmental Science and Technology 47: 5746-5754.

Grasby, S.E., B. Beauchamp, D.P.G. Bond, P.B. Wignall, and H. Sanei. 2015. Mercury anomalies associated with three extinction events (Capitanian Crisis, Latest Permian Extinction and the Smithian/Spathian Extinction) in NW Pangea. Geological Magazine 153: 285-297.

Gratz, L.E., G.J. Keeler, J.D. Blum, and L.S. Sherman. 2010. Isotopic composition and fractionation of mercury in Great Lakes precipitation and ambient air. Environmental Science and Technology 44: 7764-7770.

Gratz, L.E., J.L. Ambrose, D.A. Jaffe, V. Shah, L. Jaeglé, J. Stutz, J. Festa, M. Spolaor, et al. 2015. Oxidation of mercury by bromine in the subtropical Pacific free troposphere. Geophysical Research Letters 42: 10494-410502.

Graydon, J.A., V.L. St Louis, S.E. Lindberg, K.A. Sandilands, J.W.M. Rudd, C.A. Kelly, R. Harris, M.T. Tate, et al. 2012. The role of terrestrial vegetation in atmospheric $\mathrm{Hg}$ deposition: Pools and fluxes of spike and ambient $\mathrm{Hg}$ from the METAALICUS experiment. Global Biogeochemical Cycles 26: GB1022.

Gribble, M.O., R. Karimi, B.J. Feingold, J.F. Nyland, T.M. O'Hara, M.I. Gladyshev, and C.Y. Chen. 2016. Mercury, selenium and fish oils in marine food webs and implications for human health. Journal of Marine Biological Association UK 96: 43-59.

Grigal, D.F. 2003. Mercury sequestration in forests and peatlands: A review. Journal of Environmental Quality 32: 393-405.

Grigal, D.F., R.K. Kolka, J.A. Fleck, and E.A. Nater. 2000. Mercury budget of an upland-peatland watershed. Biogeochemistry 50: 95-109.
Guedron, S., C. Grimaldi, C. Chauvel, L. Spadini, and M. Grimaldi. 2006. Weathering versus atmospheric contributions to mercury concentrations in French Guiana soils. Applied Geochemistry 21: 2010-2022.

Gustin, M.S., S.E. Lindberg, K. Austin, M. Coolbaugh, A. Vette, and H. Zhang. 2000. Assessing the contribution of natural sources to regional atmospheric mercury budgets. Science of the Total Environment 259: 61-71.

Gustin, M.S., S.N. Lyman, P. Kilner, and E. Prestbo. 2011. Development of a passive sampler for gaseous mercury. Atmospheric Environment 45: 5805-5812.

Gustin, M.S., H.M. Amos, J. Huang, M.B. Miller, and K. Heidecorn. 2015. Measuring and modeling mercury in the atmosphere: A critical review. Atmospheric Chemistry and Physics 15: 5697-5713.

Hammerschmidt, C.R., and K.L. Bowman. 2012. Vertical methylmercury distribution in the subtropical North Pacific Ocean. Marine Chemistry 132-133: 77-82.

Hansen, K.M., J.H. Christensen, and J. Brandt. 2015. the influence of climate change on atmospheric deposition of mercury in the arctic: A model sensitivity study. International Journal of Environmental Research and Public Health 12: 11254-11268.

Hararuk, O., D. Obrist, and Y. Luo. 2013. Modeling the sensitivity of soil mercury storage to climate-induced changes in soil carbon pools. Biogeosciences 10: 2393-2407.

Harris, R.C., J.W. Rudd, M. Amyot, C.L. Babiarz, K.G. Beaty, P.J. Blanchfield, R.A. Bodaly, B.A. Branfireun, et al. 2007. Wholeecosystem study shows rapid fish-mercury response to changes in mercury deposition. Proceedings of the National Academy of Sciences 104: 16586-16591.

Haynes, K. M. 2017. Climate change impacts on mercury cycling in peatlands. Ph.D. thesis. University of Toronto, Ontario, Canada.

Haynes, K.M., E.S. Kane, L. Potvin, E.A. Lilleskov, R.K. Kolka, and C.P.J. Mitchell. 2017. Mobility and transport of mercury and methylmercury in peat as a function of changes in water table regime and plant functional groups. Global Biogeochemical Cycles 31: 233-244.

Heimbürger, L.-E., D. Cossa, J.-C. Marty, C. Migon, B. Averty, A. Dufour, and J. Ras. 2010. Methyl mercury distributions in relation to the presence of nano- and picophytoplankton in an oceanic water column (Ligurian Sea, North-western Mediterranean). Geochimica et Cosmochimica Acta 74: 5549-5559.

Heimburger, L.E., J.E. Sonke, D. Cossa, D. Point, C. Lagane, L. Laffont, B.T. Galfond, M. Nicolaus, et al. 2015. Shallow methylmercury production in the marginal sea ice zone of the central Arctic Ocean. Science Report 5: 10318.

Hermanns, Y.M., and H. Biester. 2013. Anthropogenic mercury signals in lake sediments from southernmost Patagonia, Chile. Science of the Total Environment 445-446: 126-135.

Hermanns, Y.-M., A.M. Cortizas, H. Arz, R. Stein, and H. Biester. 2012. Untangling the influence of in-lake productivity and terrestrial organic matter flux on 4,250 years of mercury accumulation in Lake Hambre, Southern Chile. Journal of Paleolimnology 49: 563-573.

Hintelmann, H., R. Harris, A. Heyes, J.P. Hurley, C.A. Kelly, D.P. Krabbenhoft, S. Lindberg, J.W. Rudd, et al. 2002. Reactivity and mobility of new and old mercury deposition in a boreal forest ecosystem during the first year of the METAALICUS study. Mercury experiment to assess atmospheric loading in Canada and the US. Environmental Science and Technology 36: 5034-5040.

Holmes, C.D., D.J. Jacob, E.S. Corbitt, J. Mao, X. Yang, R. Talbot, and F. Slemr. 2010. Global atmospheric model for mercury including oxidation by bromine atoms. Atmospheric Chemistry and Physics 10: 12037-12057. 
Horowitz, H.M., D.J. Jacob, H.M. Amos, D.G. Streets, and E.M. Sunderland. 2014. Historical mercury releases from commercial products: Global environmental implications. Environmental Science and Technology 48: 10242-10250.

Horowitz, H.M., D.J. Jacob, Y. Zhang, T.S. Dibble, F. Slemr, H.M. Amos, J.A. Schmidt, E.S. Corbitt, et al. 2017. A new mechanism for atmospheric mercury redox chemistry: Implications for the global mercury budget. Atmospheric Chemistry and Physics 17: 6353-6371.

Hsu-Kim, H., K.H. Kucharzyk, T. Zhang, and M.A. Deshusses. 2013. Mechanisms regulating mercury bioavailability for methylating microorganisms in the aquatic environment: A critical review. Environmental Science and Technology 47: 2441-2456.

Hsu-Kim, H., C.S. Eckley, D. Achá, X. Feng, C.C. Gilmour, S. Jonsson, and C.P.J. Mitchell. 2018. Challenges and opportunities for managing aquatic mercury pollution in altered landscapes. Ambio. https://doi.org/10.1007/s13280-017-1006-7.

Huang, J., and M.S. Gustin. 2015. Use of passive sampling methods and models to understand sources of mercury deposition to high elevation sites in the Western United States. Environmental Science and Technology 49: 432-441.

Hynes, A., D. Donohoue, M. Goodsite, and I. Hedgecock. 2009. Our current understanding of major chemical and physical processes affecting mercury dynamics in the atmosphere and at the airwater/terrestrial interfaces. In Mercury fate and transport in the global atmosphere, ed. R. Mason, and N. Pirrone, 427-457. New York: Springer.

Jackson, A.K., D.C. Evers, E.M. Adams, D.A. Cristol, C. EaglesSmith, S.T. Edmonds, C.E. Gray, B. Hoskins, et al. 2015. Songbirds as sentinels of mercury in terrestrial habitats of eastern North America. Ecotoxicology 24: 453-467.

Jaffe, D.A., S. Lyman, H.M. Amos, M.S. Gustin, J. Huang, N.E. Selin, L. Levin, A. ter Schure, et al. 2014. Progress on understanding atmospheric mercury hampered by uncertain measurements. Environmental Science and Technology 48: 7204-7206.

Jiao, Y., and T.S. Dibble. 2017. First kinetic study of the atmospherically important reactions $\mathrm{BrHg}+\mathrm{NO}_{2}$ and $\mathrm{BrHg}+\mathrm{HOO}$. Physical Chemistry Chemical Physics: PCCP 19: 1826-1838.

Jiskra, M., J.G. Wiederhold, U. Skyllberg, R.M. Kronberg, I. Hajdas, and R. Kretzschmar. 2015. Mercury deposition and re-emission pathways in boreal forest soils investigated with $\mathrm{Hg}$ isotope signatures. Environmental Science and Technology 49: 7188-7196.

Jiskra, M., J.G. Wiederhold, U. Skyllberg, R.M. Kronberg, and R. Kretzschmar. 2017. Source tracing of natural organic matter bound mercury in boreal forest runoff with mercury stable isotopes. Environmental Science: Process and Impacts 19: $1235-1248$.

Jonsson, S., U. Skyllberg, M.B. Nilsson, E. Lundberg, A. Andersson, and E. Bjorn. 2014. Differentiated availability of geochemical mercury pools controls methylmercury levels in estuarine sediment and biota. Nature Communications 5: 4624.

Jonsson, S., A. Andersson, M.B. Nilsson, U. Skyllberg, E. Lundberg, J.K. Schaefer, S. Akerblom, and E. Bjorn. 2017. Terrestrial discharges mediate trophic shifts and enhance methylmercury accumulation in estuarine biota. Science Advances 3: e1601239.

Jung, G., I.M. Hedgecock, and N. Pirrone. 2009. ECHMERIT V1.0: A new global fully coupled mercury-chemistry and transport model. Geoscientific Model Development 2: 175-195.

Kim, J.-H., J.-M. Park, S.-B. Lee, D. Pudasainee, and Y.-C. Seo. 2010. Anthropogenic mercury emission inventory with emission factors and total emission in Korea. Atmospheric Environment 44: 2714-2721.

Kim, H., A.L. Soerensen, J. Hur, L.E. Heimburger, D. Hahm, T.S. Rhee, S. Noh, and S. Han. 2017. Methylmercury mass budgets and distribution characteristics in the Western Pacific Ocean. Environmental Science and Technology 51: 1186-1194.

Kirk, J.L., D.C. Muir, D. Antoniades, M.S. Douglas, M.S. Evans, T.A. Jackson, H. Kling, S. Lamoureux, et al. 2011. Climate change and mercury accumulation in Canadian high and subarctic lakes. Environmental Science and Technology 45: 964-970.

Knightes, C.D., E.M. Sunderland, M. Craig Barber, J.M. Johnston, and R.B. Ambrose. 2009. Application of ecosystem-scale fate and bioaccumulation models to predict fish mercury response times to changes in atmospheric deposition. Environmental Toxicology and Chemistry 28: 881-893.

Kocman, D., S.J. Wilson, H.M. Amos, K.H. Telmer, F. Steenhuisen, E.M. Sunderland, R.P. Mason, P. Outridge, et al. 2017. Toward an assesment of the global inventory of present-day mercury releases to freshwater environments. International Journal of Environmental Research and Public Health 14: 138.

Kolka, R.K., B.R. Sturtevant, J.R. Miesel, A. Singh, P.T. Wolter, S. Fraver, T.M. DeSutter, and P.A. Townsend. 2017. Emissions of forest floor and mineral soil carbon, nitrogen and mercury pools and relationships with fire severity for the Pagami Creek Fire in the Boreal Forest of northern Minnesota. International Journal of Wildland Fire 26: 296.

Krabbenhoft, D.P., and E.M. Sunderland. 2013. Environmental science. Global change and mercury. Science 341: 1457-1458.

Kronberg, R.-M., A. Drott, M. Jiskra, J.G. Wiederhold, E. Björn, and U. Skyllberg. 2016. Forest harvest contribution to Boreal freshwater methyl mercury load. Global Biogeochemical Cycles 30: 825-843.

Kumar, A., S. Wu, Y. Huang, H. Liao, and J.O. Kaplan. 2017. Mercury from wildfires: Global emission inventories and sensitivity to 2000-2050 global change. Atmospheric Environment 173: 6-15.

Kwon, S.Y., J.D. Blum, K.J. Nadelhoffer, J. Timothy Dvonch, and M.T. Tsui. 2015. Isotopic study of mercury sources and transfer between a freshwater lake and adjacent forest food web. Science of the Total Environment 532: 220-229.

Lamborg, C.H., C.R. Hammerschmidt, G.A. Gill, R.P. Mason, and S. Gichuki. 2012. An intercomparison of procedures for the determination of total mercury in seawater and recommendations regarding mercury speciation during GEOTRACES cruises. Limnology and Oceanography: Methods 10: 90-100.

Lamborg, C.H., C.R. Hammerschmidt, K.L. Bowman, G.J. Swarr, K.M. Munson, D.C. Ohnemus, P.J. Lam, L.E. Heimburger, et al. 2014. A global ocean inventory of anthropogenic mercury based on water column measurements. Nature 512: 65-68.

Lamborg, C.H., C.R. Hammerschmidt, and K.L. Bowman. 2016. An examination of the role of particles in oceanic mercury cycling. Philosophical Transactions. Series A, Mathematical, Physical, and Engineering Sciences 374: 20150297.

Landers, D.H., S.L. Simonich, D.A. Jaffe, L.H. Geiser, D.H. Campbell, A. Schwindt, C.B. Schreck, M.L. Kent, et al. 2008. The fate, transport, and ecological impacts of airborne contaminants in western National Parks (USA). Corvallis, Oregon: Office of Research and Development, NHEERL, Western Ecology Division.

Lee, X., G. Benoit, and X. Hu. 2000. Total gaseous mercury concentration and flux over a coastal saltmarsh vegetation in Connecticut, USA. Atmospheric Environment 34: 4205-4213.

Lehnherr, I., V.L. St, H.Hintelmann Louis, and J.L. Kirk. 2011. Methylation of inorganic mercury in polar marine waters. Nature Geoscience 4: 298-302.

Lei, H., D.J. Wuebbles, X.Z. Liang, Z. Tao, S. Olsen, R. Artz, X. Ren, and M. Cohen. 2014. Projections of atmospheric mercury levels and their effect on air quality in the United States. Atmospheric Chemistry and Physics 14: 783-795. 
Lepak, R.F., R. Yin, D.P. Krabbenhoft, J.M. Ogorek, J.F. DeWild, T.M. Holsen, and J.P. Hurley. 2015. Use of Stable isotope signatures to determine mercury sources in the Great Lakes. Environmental Science \& Technology Letters 2: 335-341.

Li, M., A.T. Schartup, A.P. Valberg, J.D. Ewald, D.P. Krabbenhoft, R. Yin, P.H. Balcom, and E.M. Sunderland. 2016. Environmental origins of methylmercury accumulated in subarctic estuarine fish indicated by mercury stable isotopes. Environmental Science and Technology 50: 11559-11568.

Lin, C.-J., P. Pongprueksa, S.E. Lindberg, S.O. Pehkonen, D. Byun, and C. Jang. 2006. Scientific uncertainties in atmospheric mercury models I: Model science evaluation. Atmospheric Environment 40: 2911-2928.

Lindberg, S.E., P.J. Hanson, T.P. Meyers, and K.H. Kim. 1998. Air/surface exchange of mercury vapor over forests: The need for a reassessment of continental biogenic emissions. Atmospheric Environment 32: 895-908.

Lindberg, S., R. Bullock, R. Ebinghaus, D. Engstrom, X. Feng, W. Fitzgerald, N. Pirrone, E. Prestbo, et al. 2007. A synthesis of progress and uncertainties in attributing the sources of mercury in deposition. Ambio 36: 19-32.

Lyman, S.N., and D.A. Jaffe. 2011. Formation and fate of oxidized mercury in the upper troposphere and lower stratosphere. Nature Geoscience 5: 114-117.

Lyman, S.N., M.S. Gustin, E.M. Prestbo, P.I. Kilner, E. Edgerton, and B. Hartsell. 2009. Testing and application of surrogate surfaces for understanding potential gaseous oxidized mercury dry deposition. Environmental Science and Technology 43: 6235-6241.

Lyman, S.N., M.S. Gustin, and E.M. Prestbo. 2010a. A passive sampler for ambient gaseous oxidized mercury concentrations. Atmospheric Environment 44: 246-252.

Lyman, S.N., D.A. Jaffe, and M.S. Gustin. 2010b. Release of mercury halides from $\mathrm{KCl}$ denuders in the presence of ozone. Atmospheric Chemistry and Physics 10: 8197-8204.

MacMillan, G.A., C. Girard, J. Chetelat, I. Laurion, and M. Amyot. 2015. High methylmercury in arctic and subarctic ponds is related to nutrient levels in the warming Eastern Canadian Arctic. Environmental Science and Technology 49: 7743-7753.

Mao, H., I. Cheng, and L. Zhang. 2016. Current understanding of the driving mechanisms for spatiotemporal variations of atmospheric speciated mercury: A review. Atmospheric Chemistry and Physics 16: 12897-12924.

Martin, L.G., C. Labuschagne, E.-G. Brunke, A. Weigelt, R. Ebinghaus, and F. Slemr. 2017. Trend of atmospheric mercury concentrations at Cape Point for 1995-2004 and since 2007. Atmospheric Chemistry and Physics 17: 2393-2399.

Marusczak, N., J.E. Sonke, X. Fu, and M. Jiskra. 2017. Tropospheric GOM at the Pic du Midi Observatory: Correcting bias in denuder based observations. Environmental Science and Technology 51: 863-869.

Masbou, J., D. Point, J.E. Sonke, F. Frappart, V. Perrot, D. Amouroux, P. Richard, and P.R. Becker. 2015. Hg stable isotope time trend in ringed seals registers decreasing sea ice cover in the Alaskan Arctic. Environmental Science and Technology 49: 8977-8985.

Masekoameng, K.E., J. Leaner, and J. Dabrowski. 2010. Trends in anthropogenic mercury emissions estimated for South Africa during 2000-2006. Atmospheric Environment 44: 3007-3014.

McClure, C.D., D.A. Jaffe, and E.S. Edgerton. 2014a. Evaluation of the $\mathrm{KCl}$ denuder method for gaseous oxidized mercury using $\mathrm{HgBr} 2$ at an in-service AMNet site. Environmental Science and Technology 48: 11437-11444.

McClure, C.D., D.A. Jaffe, and E.S. Edgerton. 2014b. Evaluation of the $\mathrm{KCl}$ denuder method for gaseous oxidized mercury using
$\mathrm{HgBr} 2$ at an in-service AMNet site. Environmental Science and Technology 48: 11437-11444.

Megaritis, A.G., B.N. Murphy, P.N. Racherla, P.J. Adams, and S.N. Pandis. 2014. Impact of climate change on mercury concentrations and deposition in the eastern United States. Science of the Total Environment 487: 299-312.

Meili, M. 1991. The coupling of mercury and organic matter in the biogeochemical cycle: Towards a mechanistic model for the boreal forest zone. Water, Air, and Soil pollution 56: 333-347.

Melendez-Perez, J.J., A.H. Fostier, J.A. Carvalho, C.C. Windmöller, J.C. Santos, and A. Carpi. 2014. Soil and biomass mercury emissions during a prescribed fire in the Amazonian rain forest. Atmospheric Environment 96: 415-422.

Mitchell, C.P., R.K. Kolka, and S. Fraver. 2012. Singular and combined effects of blowdown, salvage logging, and wildfire on forest floor and soil mercury pools. Environmental Science and Technology 46: 7963-7970.

Moore, C.W., and M.S. Castro. 2012. Investigation of factors affecting gaseous mercury concentrations in soils. Science of the Total Environment 419: 136-143.

Muir, D.C., X. Wang, F. Yang, N. Nguyen, T.A. Jackson, M.S. Evans, M. Douglas, G. Kock, et al. 2009. Spatial trends and historical deposition of mercury in eastern and northern Canada inferred from lake sediment cores. Environmental Science and Technology 43: 4802-4809.

Munson, K.M., C.H. Lamborg, G.J. Swarr, and M.A. Saito. 2015. Mercury species concentrations and fluxes in the Central Tropical Pacific Ocean. Global Biogeochemical Cycles 29: 656-676.

Muntean, M., G. Janssens-Maenhout, S. Song, N.E. Selin, J.G. Olivier, D. Guizzardi, R. Maas, and F. Dentener. 2014. Trend analysis from 1970 to 2008 and model evaluation of EDGARv4 global gridded anthropogenic mercury emissions. Science of the Total Environment 494-495: 337-350.

Nansai, K., M. Oguchi, N. Suzuki, A. Kida, T. Nataami, C. Tanaka, and M. Haga. 2012. High-resolution inventory of Japanese anthropogenic mercury emissions. Environmental Science and Technology 46: 4933-4940.

Navrátil, T., J. Shanley, J. Rohovec, M. Hojdová, V. Penížek, and J. Buchtová. 2014. Distribution and pools of mercury in Czech forest soils. Water, Air, and Soil pollution 225: 1829.

Navrátil, T., J.B. Shanley, J. Rohovec, F. Oulehle, M. Šimeček, J. Houška, and P. Cudlín. 2016. Soil mercury distribution in adjacent coniferous and deciduous stands highly impacted by acid rain in the Ore Mountains, Czech Republic. Applied Geochemistry 75: 63-75.

Ndu, U., T. Barkay, R.P. Mason, A. Traore Schartup, R. Al-Farawati, J. Liu, and J.R. Reinfelder. 2015. The use of a mercury biosensor to evaluate the bioavailability of mercury-thiol complexes and mechanisms of mercury uptake in bacteria. PLOS ONE 10: $\mathrm{e} 0138333$.

Nelson, P.F., A.L. Morrison, H.J. Malfroy, M. Cope, S. Lee, M.L. Hibberd, C.P. Meyer, and J. McGregor. 2012. Atmospheric mercury emissions in Australia from anthropogenic, natural and recycled sources. Atmospheric Environment 62: 291-302.

Nerentorp Mastromonaco, M., K. Gårdfeldt, B. Jourdain, K. Abrahamsson, A. Granfors, M. Ahnoff, A. Dommergue, G. Méjean, et al. 2016. Antarctic winter mercury and ozone depletion events over sea ice. Atmospheric Environment 129: 125-132.

Obrist, D. 2007. Atmospheric mercury pollution due to losses of terrestrial carbon pools? Biogeochemistry 85: 119-123.

Obrist, D. 2012. Mercury distribution across 14 U.S. forests. Part II: Patterns of methyl mercury concentrations and areal mass of total and methyl mercury. Environmental Science and Technology 46: 5921-5930. 
Obrist, D., M.S. Gustin, J.A. Arnone, D.W. Johnson, D.E. Schorran, and P.S.J. Verburg. 2005. Measurements of gaseous elemental mercury fluxes over intact tallgrass prairie monoliths during one full year. Atmospheric Environment 39: 957-965.

Obrist, D., D.W. Johnson, S.E. Lindberg, Y. Luo, O. Hararuk, R. Bracho, J.J. Battles, D.B. Dail, et al. 2011. Mercury distribution across 14 U.S. Forests. Part I: Spatial patterns of concentrations in biomass, litter, and soils. Environmental Science and Technology 45: 3974-3981.

Obrist, D., D.W. Johnson, and R.L. Edmonds. 2012. Effects of vegetation type on mercury concentrations and pools in two adjacent coniferous and deciduous forests. Journal of Plant Nutrition and Soil Science 175: 68.

Obrist, D., A.K. Pokharel, and C. Moore. 2014. Vertical profile measurements of soil air suggest immobilization of gaseous elemental mercury in mineral soil. Environmental Science and Technology 48: 2242-2252.

Obrist, D., C. Pearson, J. Webster, T. Kane, C.J. Lin, G.R. Aiken, and C.N. Alpers. 2016. A synthesis of terrestrial mercury in the western United States: Spatial distribution defined by land cover and plant productivity. Science of the Total Environment 568: 522-535.

Obrist, D., Y. Agnan, M. Jiskra, C.L. Olson, D.P. Colegrove, J. Hueber, C.W. Moore, J.E. Sonke, et al. 2017. Tundra uptake of atmospheric elemental mercury drives Arctic mercury pollution. Nature 547: 201-204.

Ortiz, V.L., R.P. Mason, and J.E. Ward. 2015. An examination of the factors influencing mercury and methylmercury particulate distributions, methylation and demethylation rates in laboratory-generated marine snow. Marine Chemistry 177: 753-762.

Outridge, P.M., N. Rausch, J.B. Percival, W. Shotyk, and R. McNeely. 2011. Comparison of mercury and zinc profiles in peat and lake sediment archives with historical changes in emissions from the Flin Flon metal smelter, Manitoba, Canada. Science of the Total Environment 409: 548-563.

Pacyna, E.G., J.M. Pacyna, K. Sundseth, J. Munthe, K. Kindbom, S. Wilson, F. Steenhuisen, and P. Maxson. 2010. Global emission of mercury to the atmosphere from anthropogenic sources in 2005 and projections to 2020. Atmospheric Environment 44: $2487-2499$.

Pacyna, J.M., O. Travnikov, F. De Simone, I.M. Hedgecock, K. Sundseth, E.G. Pacyna, F. Steenhuisen, N. Pirrone, et al. 2016. Current and future levels of mercury atmospheric pollution on a global scale. Atmospheric Chemistry and Physics 16: 12495-12511.

Parks, J.M., A. Johs, M. Podar, R. Bridou, R.A. Hurt Jr., S.D. Smith, S.J. Tomanicek, Y. Qian, et al. 2013. The genetic basis for bacterial mercury methylation. Science 339: 1332-1335.

Peña-Rodríguez, S., X. Pontevedra-Pombal, D. Fernández-Calviño, T. Taboada, M. Arias-Estévez, A. Martínez-Cortizas, J.C. NóvoaMuñoz, and E. García-Rodeja. 2012. Mercury content in volcanic soils across Europe and its relationship with soil properties. Journal of Soils and Sediments 12: 542-555.

Peña-Rodríguez, S., X. Pontevedra-Pombal, E.G.-R. Gayoso, A. Moretto, R. Mansilla, L. Cutillas-Barreiro, M. Arias-Estévez, and J.C. Nóvoa-Muñoz. 2014. Mercury distribution in a toposequence of sub-Antarctic forest soils of Tierra del Fuego (Argentina) as consequence of the prevailing soil processes. Geoderma 232-234: 130-140.

Perry, E., S.A. Norton, N.C. Kamman, P.M. Lorey, and C.T. Driscoll. 2005. Deconstruction of historic mercury accumulation in lake sediments, northeastern United States. Ecotoxicology 14: 85-99.

Pirrone, N., S. Cinnirella, X. Feng, R.B. Finkelman, H.R. Friedli, J. Leaner, R. Mason, A.B. Mukherjee, et al. 2010. Global mercury emissions to the atmosphere from anthropogenic and natural sources. Atmospheric Chemistry and Physics 10: 5951-5964.
Pirrone, N., W. Aas, S. Cinnirella, R. Ebinghaus, I.M. Hedgecock, J. Pacyna, F. Sprovieri, and E.M. Sunderland. 2013. Toward the next generation of air quality monitoring: Mercury. Atmospheric Environment 80: 599-611.

Podar, M., C.C. Gilmour, C.C. Brandt, A. Soren, S.D. Brown, B.R. Crable, A.V. Palumbo, A.C. Somenahally, et al. 2015. Global prevalence and distribution of genes and microorganisms involved in mercury methylation. Science Advances 1: e1500675.

Point, D., J.E. Sonke, R.D. Day, D.G. Roseneau, K.A. Hobson, S.S. Vander Pol, A.J. Moors, R.S. Pugh, et al. 2011. Methylmercury photodegradation influenced by sea-ice cover in Arctic marine ecosystems. Nature Geoscience 4: 188-194.

Prestbo, E.M., and D.A. Gay. 2009. Wet deposition of mercury in the U.S. and Canada, 1996-2005: Results and analysis of the NADP mercury deposition network (MDN). Atmospheric Environment 43: 4223-4233.

Rafaj, P., I. Bertok, J. Cofala, and W. Schöpp. 2013. Scenarios of global mercury emissions from anthropogenic sources. Atmospheric Environment 79: 472-479.

Richardson, J.B., and A.J. Friedland. 2015. Mercury in coniferous and deciduous upland forests in Northern New England, USA: Implications from climate change. Biogeosciences Discussions 12: $11463-11498$.

Richardson, J.B., A.J. Friedland, T.R. Engerbretson, J.M. Kaste, and B.P. Jackson. 2013. Spatial and vertical distribution of mercury in upland forest soils across the northeastern United States. Environmental Pollution 182: 127-134.

Risch, M.R., J.F. Dewild, D.P. Krabbenhoft, R.K. Kolka, and L. Zhang. 2012a. Litterfall mercury dry deposition in the eastern USA. Environmental Pollution 161: 284-290.

Risch, M.R., D.A. Gay, K.K. Fowler, G.J. Keeler, S.M. Backus, P. Blanchard, J.A. Barres, and J.T. Dvonch. 2012b. Spatial patterns and temporal trends in mercury concentrations, precipitation depths, and mercury wet deposition in the North American Great Lakes region, 2002-2008. Environmental Pollution 161: 261-271.

Rydberg, J., M. Rosch, E. Heinz, and H. Biester. 2015. Influence of catchment vegetation on mercury accumulation in lake sediments from a long-term perspective. Science of the Total Environment 538: 896-904.

Schaefer, J.K., R.M. Kronberg, F.M. Morel, and U. Skyllberg. 2014. Detection of a key $\mathrm{Hg}$ methylation gene, hgcA, in wetland soils. Environmental Microbiology Reports 6: 441-447.

Schartup, A.T., P.H. Balcom, A.L. Soerensen, K.J. Gosnell, R.S. Calder, R.P. Mason, and E.M. Sunderland. 2015. Freshwater discharges drive high levels of methylmercury in Arctic marine biota. Proceedings of the National Academy of Sciences United States of America 112: 11789-11794.

Schauble, E.A. 2007. Role of nuclear volume in driving equilibrium stable isotope fractionation of mercury, thallium, and other very heavy elements. Geochimica et Cosmochimica Acta 71: 2170-2189.

Schwesig, D., and E. Matzner. 2000. Pools and fluxes of mercury and methylmercury in two forested catchments in Germany. Science of the Total Environment 260: 213-223.

Selin, N.E. 2014. Global change and mercury cycling: Challenges for implementing a global mercury treaty. Environmental Toxicology and Chemistry 33: 1202-1210.

Selin, N.E., D.J. Jacob, R.J. Park, R.M. Yantosca, S. Strode, L. Jaegle, and D. Jaffe. 2007. Chemical cycling and deposition of atmospheric mercury: Global constraints from observations. Journal of Geophysical Research 112: D02308.

Selin, N.E., D.J. Jacob, R.M. Yantosca, S. Strode, L. Jaeglé, and E.M. Sunderland. 2008. Global 3-D land-ocean-atmosphere model for mercury: Present-day versus preindustrial cycles and 
anthropogenic enrichment factors for deposition. Global Biogeochemical Cycles. https://doi.org/10.1029/2007GB003040.

Selin, H., S.E. Keane, S. Wang, N.E. Selin, K. Davis, and D. Bally. 2018. Linking science and policy to support the implementation of the Minamata Convention on Mercury. Ambio. https://doi.org/ 10.1007/s13280-017-1003-x.

Semeniuk, K., and A. Dastoor. 2017. Development of a global ocean mercury model with a methylation cycle: Outstanding issues. Global Biogeochemical Cycles 31: 400-433.

Senn, D.B., E.J. Chesney, J.D. Blum, M.S. Bank, A. Maage, and J.P. Shine. 2010. Stable isotope (N, C, Hg) study of methylmercury sources and trophic transfer in the northern gulf of Mexico. Environmental Science and Technology 44: 1630-1637.

Shah, V., L. Jaeglé, L.E. Gratz, J.L. Ambrose, D.A. Jaffe, N.E. Selin, S. Song, T.L. Campos, et al. 2016. Origin of oxidized mercury in the summertime free troposphere over the southeastern US. Atmospheric Chemistry and Physics 16: 1511-1530.

Sherman, L.S., and J.D. Blum. 2013. Mercury stable isotopes in sediments and largemouth bass from Florida lakes, USA. Science of the Total Environment 448: 163-175.

Sherman, L.S., J.D. Blum, K.P. Johnson, G.J. Keeler, J.A. Barres, and T.A. Douglas. 2010. Mass-independent fractionation of mercury isotopes in Arctic snow driven by sunlight. Nature Geoscience 3: 173-177.

Sherman, L.S., J.D. Blum, G.J. Keeler, J.D. Demers, and J.T. Dvonch. 2012. Investigation of local mercury deposition from a coal-fired power plant using mercury isotopes. Environmental Science and Technology 46: 382-390.

Sigler, J.M., and X. Lee. 2006. Gaseous mercury in background forest soil in the northeastern United States. Journal of Geophysical Research: Biogeosciences 111: G02007.

Slemr, F., E.-G. Brunke, R. Ebinghaus, C. Temme, J. Munthe, I. Wängberg, W. Schroeder, A. Steffen, et al. 2003. Worldwide trend of atmospheric mercury since 1977. Geophysical Research Letters 30: 1516.

Slemr, F., E.G. Brunke, C. Labuschagne, and R. Ebinghaus. 2008. Total gaseous mercury concentrations at the Cape Point GAW station and their seasonality. Geophysical Research Letters 35: L11807.

Slemr, F., E.G. Brunke, R. Ebinghaus, and J. Kuss. 2011. Worldwide trend of atmospheric mercury since 1995. Atmospheric Chemistry and Physics 11: 4779-4787.

Slemr, F., A. Weigelt, R. Ebinghaus, C. Brenninkmeijer, A. Baker, T. Schuck, A. Rauthe-Schöch, H. Riede, et al. 2014. Mercury plumes in the global upper troposphere observed during flights with the CARIBIC observatory from May 2005 until June 2013. Atmosphere 5: 342-369.

Slemr, F., C.A. Brenninkmeijer, A. Rauthe-Schöch, A. Weigelt, R. Ebinghaus, E.-G. Brunke, L. Martin, T.G. Spain, et al. 2016. El Niño-Southern Oscillation influence on tropospheric mercury concentrations. Geophysical Research Letters 43: 1766-1771.

Smith-Downey, N.V., E.M. Sunderland, and D.J. Jacob. 2010. Anthropogenic impacts on global storage and emissions of mercury from terrestrial soils: Insights from a new global model. Journal of Geophysical Research 115: G03008.

Soerensen, A.L., E.M. Sunderland, C.D. Holmes, D.J. Jacob, R.M. Yantosca, H. Skov, J.H. Christensen, S.A. Strode, et al. 2010. An improved global model for air-sea exchange of mercury: High concentrations over the North Atlantic. Environmental Science and Technology 44: 8574-8580.

Soerensen, A.L., D.J. Jacob, D.G. Streets, M.L.I. Witt, R. Ebinghaus, R.P. Mason, M. Andersson, and E.M. Sunderland. 2012. Multidecadal decline of mercury in the North Atlantic atmosphere explained by changing subsurface seawater concentrations. Geophysical Research Letters. https://doi.org/10.1029/ 2012GL053736.
Soerensen, A.L., R.P. Mason, P.H. Balcom, and E.M. Sunderland. 2013. Drivers of surface ocean mercury concentrations and airsea exchange in the West Atlantic Ocean. Environmental Science and Technology 47: 7757-7765.

Soerensen, A.L., R.P. Mason, P.H. Balcom, D.J. Jacob, Y. Zhang, J. Kuss, and E.M. Sunderland. 2014. Elemental mercury concentrations and fluxes in the tropical atmosphere and ocean. Environmental Science and Technology 48: 11312-11319.

Soerensen, A.L., D.J. Jacob, A.T. Schartup, J.A. Fisher, I. Lehnherr, V.L. St. Louis, L.-E. Heimbürger, J.E. Sonke, et al. 2016. A mass budget for mercury and methylmercury in the Arctic Ocean. Global Biogeochemical Cycles 30: 560-575.

Sommar, J., W. Zhu, L. Shang, C.-J. Lin, and X. Feng. 2016. Seasonal variations in metallic mercury $\left(\mathrm{Hg}^{0}\right)$ vapor exchange over biannual wheat-corn rotation cropland in the North China Plain. Biogeosciences 13: 2029-2049.

Song, S., N.E. Selin, A.L. Soerensen, H. Angot, R. Artz, S. Brooks, E.G. Brunke, G. Conley, et al. 2015. Top-down constraints on atmospheric mercury emissions and implications for global biogeochemical cycling. Atmospheric Chemistry and Physics 15: $7103-7125$.

Song, S., N.E. Selin, LE Gratz, J.L. Ambrose, D.A. Jaffe, V. Shah, L. Jaeglé, A. Giang, et al. 2016. Constraints from observations and modeling on atmosphere-surface exchange of mercury in eastern North America. Elementa: Science of the Anthropocene 4: 100.

Sonke, J.E. 2011. A global model of mass independent mercury stable isotope fractionation. Geochimica et Cosmochimica Acta 75: 4577-4590.

Sonke, J.E., J. Schäfer, J. Chmeleff, S. Audry, G. Blanc, and B. Dupré. 2010. Sedimentary mercury stable isotope records of atmospheric and riverine pollution from two major European heavy metal refineries. Chemical Geology 279: 90-100.

Sprovieri, F., N. Pirrone, R. Ebinghaus, H. Kock, and A. Dommergue. 2010. A review of worldwide atmospheric mercury measurements. Atmospheric Chemistry and Physics 10: 8245-8265.

Sprovieri, F., N. Pirrone, M. Bencardino, F. D’Amore, F. Carbone, S. Cinnirella, V. Mannarino, M. Landis, et al. 2016. Atmospheric mercury concentrations observed at ground-based monitoring sites globally distributed in the framework of the GMOS network. Atmospheric Chemistry and Physics 16: 11915-11935.

Sprovieri, F., N. Pirrone, M. Bencardino, F. D'Amore, H. Angot, C. Barbante, E.-G. Brunke, F. Arcega-Cabrera, et al. 2017. Fiveyear records of mercury wet deposition flux at GMOS sites in the Northern and Southern hemispheres. Atmospheric Chemistry and Physics 17: 2689-2708.

St. Louis, V., J. Graydon, C. Mitchell, and C. Oswald. 2016. Mercury fate and methylation in terrestrial upland and wetland environments In Canada Mercury Science Assessment.

Stern, G.A., R.W. Macdonald, P.M. Outridge, S. Wilson, J. Chetelat, A. Cole, H. Hintelmann, L.L. Loseto, et al. 2012. How does climate change influence Arctic mercury? Science of the Total Environment 414: 22-42.

Streets, D., J. Hao, Y. Wu, J. Jiang, M. Chan, H. Tian, and X. Feng. 2005. Anthropogenic mercury emissions in China. Atmospheric Environment 39: 7789-7806.

Streets, D.G., Q. Zhang, and Y. Wu. 2009. Projections of global mercury emissions in 2050. Environmental Science and Technology 43: 2983-2988.

Streets, D.G., M.K. Devane, Z. Lu, T.C. Bond, E.M. Sunderland, and D.J. Jacob. 2011. All-time releases of mercury to the atmosphere from human activities. Environmental Science and Technology 45: 10485-10491.

Streets, D.G., H.M. Horowitz, D.J. Jacob, Z. Lu, L. Levin, A.F.H. Ter Schure, and E.M. Sunderland. 2017. Total mercury released to the environment by human activities. Environmental Science and Technology 51: 5969-5977. 
Strode, S.A., L. Jaeglé, N.E. Selin, D.J. Jacob, R.J. Park, R.M. Yantosca, R.P. Mason, and F. Slemr. 2007. Air-sea exchange in the global mercury cycle. Global Biogeochemical Cycles. https:// doi.org/10.1029/2006GB002766.

Subir, M., P.A. Ariya, and A.P. Dastoor. 2011. A review of uncertainties in atmospheric modeling of mercury chemistry I. Uncertainties in existing kinetic parameters: Fundamental limitations and the importance of heterogeneous chemistry. Atmospheric Environment 45: 5664-5676.

Sun, G., J. Sommar, X. Feng, C.J. Lin, M. Ge, W. Wang, R. Yin, X. Fu, et al. 2016a. Mass-dependent and -independent fractionation of mercury isotope during gas-phase oxidation of elemental mercury vapor by atomic $\mathrm{Cl}$ and $\mathrm{Br}$. Environmental Science and Technology 50: 9232-9241.

Sun, R., D.G. Streets, H.M. Horowitz, H.M. Amos, G. Liu, V. Perrot, J.-P. Toutain, H. Hintelmann, et al. 2016b. Historical (1850-2010) mercury stable isotope inventory from anthropogenic sources to the atmosphere. Elementa: Science of the Anthropocene 4: 000091.

Sunderland, E.M. 2007. Mercury exposure from domestic and imported estuarine and marine fish in the U.S. seafood market. Environmental Health Perspectives 115: 235-242.

Sunderland, E.M., and R.P. Mason. 2007. Human impacts on open ocean mercury concentrations. Global Biogeochemical Cycles. https://doi.org/10.1029/2006GB002876.

Sunderland, E.M., D.P. Krabbenhoft, J.W. Moreau, S.A. Strode, and W.M. Landing. 2009. Mercury sources, distribution, and bioavailability in the North Pacific Ocean: Insights from data and models. Global Biogeochemical Cycles. https://doi.org/10. 1029/2008GB003425.

Sunderland, E.M., J. Dalziel, A. Heyes, B.A. Branfireun, D.P. Krabbenhoft, and F.A.P.C. Gobas. 2010. Response of a macrotidal estuary to changes in anthropogenic mercury loading between 1850 and 2000. Environmental Science and Technology 44: $1698-1704$.

Temme, C., P. Blanchard, A. Steffen, C. Banic, S. Beauchamp, L. Poissant, R. Tordon, and B. Wiens. 2007. Trend, seasonal and multivariate analysis study of total gaseous mercury data from the Canadian atmospheric mercury measurement network (CAMNet). Atmospheric Environment 41: 5423-5441.

Tørseth, K., W. Aas, K. Breivik, A.M. Fjæraa, M. Fiebig, A.G. Hjellbrekke, C. Lund Myhre, S. Solberg, et al. 2012. Introduction to the European Monitoring and Evaluation Programme (EMEP) and observed atmospheric composition change during 1972-2009. Atmospheric Chemistry and Physics 12: 5447-5481.

Townsend, J.M., C.T. Driscoll, C.C. Rimmer, and K.P. McFarland. 2014. Avian, salamander, and forest floor mercury concentrations increase with elevation in a terrestrial ecosystem. Environmental Toxicology and Chemistry 33: 208-215.

Travnikov, O., and I. Ilyin. 2009. The EMEP/MSC-E Mercury Modeling System. In Mercury fate and transport in the global atmosphere: Emissions, measurements, and models, ed. N. Pirrone, and R.P. Mason. Berlin: Springer.

Travnikov, O., H. Angot, P. Artaxo, M. Bencardino, J. Bieser, F. D'Amore, A. Dastoor, F. De Simone, et al. 2017. Multi-model study of mercury dispersion in the atmosphere: Atmospheric processes and model evaluation. Atmospheric Chemistry and Physics 17: 5271-5295.

Tsui, M.T., J.D. Blum, S.Y. Kwon, J.C. Finlay, S.J. Balogh, and Y.H. Nollet. 2012. Sources and transfers of methylmercury in adjacent river and forest food webs. Environmental Science and Technology 46: 10957-10964.

Ullrich, S.M., T.W. Tanton, and S.A. Abdrashitova. 2001. Mercury in the aquatic environment: A review of factors affecting methylation. Critical Reviews in Environmental Science and Technology 31: 241-293.
UNEP. 2013. Global Mercury Assessment 2013: Sources, Emissions, Releases and Environmental Transport. Geneva: United Nations Environment Programme.

United Nations Environment Programme. 2013. Global mercury assessment 2013: Sources, emissions, releases, and environmental transport. Geneva: UNEP Chemicals Branch.

US EPA. 2015. 2011 National Emissions Inventory (version 2) Technical Support Document. United States Environmental Protection Agency, Research Triangle Park, NC.

Wang, S.X., J.X. Song, G.H. Li, Y. Wu, L. Zhang, Q. Wan, D.G. Streets, C.K. Chin, et al. 2010. Estimating mercury emissions from a zinc smelter in relation to China's mercury control policies. Environmental Pollution 158: 3347-3353.

Wang, F., A. Saiz-Lopez, A.S. Mahajan, J.C. Gómez Martín, D. Armstrong, M. Lemes, T. Hay, and C. Prados-Roman. 2014. Enhanced production of oxidised mercury over the tropical Pacific Ocean: A key missing oxidation pathway. Atmospheric Chemistry and Physics 14: 1323-1335.

Wang, X., Z. Bao, C.-J. Lin, W. Yuan, and X. Feng. 2016. Assessment of global mercury deposition through litterfall. Environmental Science and Technology 50: 8548-8557.

Wang, X., J. Luo, R. Yin, W. Yuan, C.J. Lin, J. Sommar, X. Feng, H. Wang, et al. 2017. Using mercury isotopes to understand mercury accumulation in the montane forest floor of the Eastern Tibetan Plateau. Environmental Science and Technology 51: 801-809.

Webster, J.P., T.J. Kane, D. Obrist, J.N. Ryan, and G.R. Aiken. 2016. Estimating mercury emissions resulting from wildfire in forests of the Western United States. Science of the Total Environment 568: 578-586.

Weigelt, A., R. Ebinghaus, A.J. Manning, R.G. Derwent, P.G. Simmonds, T.G. Spain, S.G. Jennings, and F. Slemr. 2015. Analysis and interpretation of 18 years of mercury observations since 1996 at Mace Head, Ireland. Atmospheric Environment 100: 85-93.

Weiss-Penzias, P.S., D.A. Gay, M.E. Brigham, M.T. Parsons, M.S. Gustin, and A. Ter Schure. 2016. Trends in mercury wet deposition and mercury air concentrations across the U.S. and Canada. Science of the Total Environment 568: 546-556.

Westerling, A.L., H.G. Hidalgo, D.R. Cayan, and T.W. Swetnam. 2006. Warming and earlier spring increase western U.S. forest wildfire activity. Science 313: 940-943.

Wiederhold, J.G., C.J. Cramer, K. Daniel, I. Infante, B. Bourdon, and R. Kretzschmar. 2010. Equilibrium mercury isotope fractionation between dissolved $\mathrm{Hg}(\mathrm{II})$ species and thiol-bound $\mathrm{Hg}$. Environmental Science and Technology 44: 4191-4197.

Wiedinmyer, C., and H. Friedli. 2007. Mercury emission estimates from fires: An initial inventory for the United States. Environmental Science and Technology 41: 8092-8098.

Woodruff, L.G., and W.F. Cannon. 2010. Immediate and long-term fire effects on total mercury in forests soils of northeastern Minnesota. Environmental Science and Technology 44: 5371-5376.

Wright, L.P., L. Zhang, and F.J. Marsik. 2016. Overview of mercury dry deposition, litterfall, and throughfall studies. Atmospheric Chemistry and Physics 16: 13399-13416.

Yang, Y., R.D. Yanaia, M. Montesdeoca, and C.T. Driscoll. 2017. Measuring mercury in wood: Challenging but important. International Journal of Environmental Analytical Chemistry 97: 456.

Ye, Z., H. Mao, C.-J. Lin, and S.Y. Kim. 2016. Investigation of processes controlling summertime gaseous elemental mercury oxidation at midlatitudinal marine, coastal, and inland sites. Atmospheric Chemistry and Physics 16: 8461-8478. 
Yu, R.Q., J.R. Reinfelder, M.E. Hines, and T. Barkay. 2013. Mercury methylation by the methanogen Methanospirillum hungatei. Applied and Environmental Microbiology 79: 6325-6330.

Yu, B., X. Fu, R. Yin, H. Zhang, X. Wang, C.-J. Lin, C. Wu, Y. Zhang, et al. 2016. Isotopic composition of atmospheric mercury in China: New evidence for source and transformation processes in air and in vegetation. Environmental Science and Technology 50: 9262-9269.

Zhang, Y., and L. Jaeglé. 2013. Decreases in mercury wet deposition over the United States during 2004-2010: Roles of domestic and global background emission reductions. Atmosphere 4: 113-131.

Zhang, L., L.P. Wright, and P. Blanchard. 2009. A review of current knowledge concerning dry deposition of atmospheric mercury. Atmospheric Environment 43: 5853-5864.

Zhang, L., S. Wang, Q. Wu, Y. Meng, H. Yang, F. Wang, and J. Hao. 2012. Were mercury emission factors for Chinese non-ferrous metal smelters overestimated? Evidence from onsite measurements in six smelters. Environmental Pollution 171: 109-117.

Zhang, H., R.S. Yin, X.B. Feng, J. Sommar, C.W. Anderson, A. Sapkota, X.W. Fu, and T. Larssen. 2013. Atmospheric mercury inputs in montane soils increase with elevation: Evidence from mercury isotope signatures. Science Reports 3: 3322.

Zhang, Y., L. Jaeglé, and L. Thompson. 2014. Natural biogeochemical cycle of mercury in a global three-dimensional ocean tracer model. Global Biogeochemical Cycles 28: 553-570.

Zhang, L., S. Wang, L. Wang, Y. Wu, L. Duan, Q. Wu, F. Wang, M. Yang, et al. 2015a. Updated emission inventories for speciated atmospheric mercury from anthropogenic sources in China. Environmental Science and Technology 49: 3185-3194.

Zhang, Y., D.J. Jacob, S. Dutkiewicz, H.M. Amos, M.S. Long, and E.M. Sunderland. 2015b. Biogeochemical drivers of the fate of riverine mercury discharged to the global and Arctic oceans. Global Biogeochemical Cycles 29: 854-864.

Zhang, H., C.D. Holmes, and S. Wu. 2016a. Impacts of changes in climate, land use and land cover on atmospheric mercury. Atmospheric Environment 141: 230-244.

Zhang, L., S. Wang, Q. Wu, F. Wang, C.-J. Lin, L. Zhang, M. Hui, M. Yang, et al. 2016b. Mercury transformation and speciation in flue gases from anthropogenic emission sources: A critical review. Atmospheric Chemistry and Physics 16: 2417-2433.

Zhang, L., Z. Wu, I. Cheng, L.P. Wright, M.L. Olson, D.A. Gay, M.R. Risch, S. Brooks, et al. 2016c. The estimated six-year mercury dry deposition across North America. Environmental Science and Technology 50: 12864-12873.

Zhang, Y., D.J. Jacob, H.M. Horowitz, L. Chen, H.M. Amos, D.P. Krabbenhoft, F. Slemr, V.L. St Louis, et al. 2016d. Observed decrease in atmospheric mercury explained by global decline in anthropogenic emissions. Proceedings of the National Academy of Sciences of the United States of America 113: 526-531.

Zheng, W., D. Obrist, D. Weis, and B.A. Bergquist. 2016. Mercury isotope compositions across North American forests. Global Biogeochemical Cycles 30: 1475-1492.

Zhu, W., C.-J. Lin, X. Wang, J. Sommar, X. Fu, and X. Feng. 2016. Global observations and modeling of atmosphere-surface exchange of elemental mercury: A critical review. Atmospheric Chemistry and Physics 16: 4451-4480.

\section{AUTHOR BIOGRAPHIES}

Daniel Obrist $(\bowtie)$ is a Professor and Chair in the Department of Environmental, Earth \& Atmospheric Sciences at University of Massachusetts Lowell. His research aims to understand the fate of persistent pollutants and greenhouse gases in the environment, with an emphasis on mercury contamination. His research spans atmospheric chemistry, soil chemistry, and biogeochemistry as well as surface-atmosphere exchange studies.
Address: Department of Environmental, Earth and Atmospheric Sciences, University of Massachusetts, Lowell, One University Ave, Lowell, MA 01854, USA.

e-mail: daniel_obrist@uml.edu

Jane L. Kirk has been a research scientist with the Aquatic Contaminants Research Division of Environment and Climate Change Canada at the Canada Centre for Inland Waters since 2009. She has also been an adjunct Assistant Professor at the University of Toronto Mississauga and at Queen's University. She studies the biogeochemical cycling of elements and contaminants in the environment. Her recent studies have focused on the deposition, transformation, and bioaccumulation of mercury and metals in aquatic ecosystems undergoing change, including atmospheric deposition of contaminants in the Alberta Oil Sands region; the impact of multiple stressors, such as climate change and eutrophication, on mercury cycling in freshwater ecosystems, including the high and sub-Arctic; and the deposition and bioaccumulation of mercury downwind of major point sources.

Address: Environment and Climate Change, Canada, 867 Lakeshore Road, Burlington, ON L7P 2X3, Canada.

e-mail: jane.kirk@canada.ca

Lei Zhang is an Associate Professor in the School of the Environment at Nanjing University, China. His research focuses on mercury emission, transport and fate in the atmospheric environment, and mercury emission control technologies and strategies. His research group is currently participating in a project on the evaluation of potential benefits from control strategies in China in response to the Minamata Convention on Mercury.

Address: School of the Environment, Nanjing University, 163 Xianlin Avenue, Nanjing 210023, Jiangsu, China.

e-mail: lzhang12@nju.edu.cn

Elsie M. Sunderland is the Thomas D. Cabot Associate Professor of Environmental Science and Engineering in the Harvard John A. Paulson School of Engineering and Applied Science. She holds a secondary appointment in the Department of Environmental Health in the Harvard T.H. Chan School of Public Health. Her research group (http://bgc.seas.harvard.edu) studies the biogeochemistry of global contaminants. Her work aims to better understand how global contaminants are distributed in the environment and how global climate change and industrial development will affect future health risks.

Address: Harvard John A. Paulson School of Engineering and Applied Sciences, Harvard T.H. Chan School of Public Health, Harvard University, 29 Oxford Street, Cambridge, MA 02138, USA. e-mail: ems@seas.harvard.edu

Martin Jiskra is currently a Research Associate at the Department of Environmental Geosciences at the University of Basel, Switzerland. His research focuses on the development of $\mathrm{Hg}$ stable isotopes as tracer for sources and processes in the environment. His main research interests are the exchange of mercury between the atmosphere and terrestrial ecosystems as well as transformation and transport processes in soils. He has recently been working on boreal and Arctic ecosystems.

Present Address: Environmental Geosciences, University of Basel, Bernoullistr. 30, 4056 Basel, Switzerland.

Address: Géosciences Environnement Toulouse, GET-CNRS, CNRS

- OMP, 14 Avenue Edouard Belin, 31400 Toulouse, France.

e-mail: martin.jiskra@unibas.ch

Noelle E. Selin is an Associate Professor in the Institute for Data, Systems, and Society, and the Department of Earth, Atmospheric, and Planetary Sciences, at the Massachusetts Institute of Technology. Her research uses atmospheric chemistry modeling to understand the 
global fate and transport of mercury and other pollutants. Her work also addresses the interactions between science and policy on hazardous substances.

Address: Institute for Data, Systems, and Society and Department of Earth, Atmospheric and Planetary Sciences, Massachusetts Institute of Technology, 77 Massachusetts Avenue, Cambridge, MA 02139, USA.

e-mail: selin@mit.edu 